\title{
Independent invention in Italy during the Liberal Age, 1861-1913
}

\section{By ALESSANDRO NUVOLARI and MICHELANGELO VASTA*}

\begin{abstract}
This article examines the phenomenon of independent invention in Italy during the Liberal Age (1861-1913). It makes use of a new dataset comprising all patents granted in Italy in five benchmark years: 1864-5, 1881, 1891, 1902, and 1911. The following exercises are carried out. First, an examination is undertaken of the shares of independent, corporate, and foreign inventions and their evolution over time and across industries. Second, by exploiting the peculiarities of Italian patent legislation, which was characterized by relatively cheap fees and a flexible renewal scheme, the relative quality of independent and corporate patents is assessed. The results indicate that in Italy independent inventors made an important contribution to technological change in terms of number of patents, but the quality of their patents was significantly lower than that of firms and of foreign patentees.
\end{abstract}

$\mathrm{F}$ ollowing Schumpeter, it has been frequently suggested that during the second industrial revolution there was a major shift in the nature of inventive activities from individuals to the research laboratories of large firms, a process that Bernal eloquently dubbed 'the industrialization of invention'. ${ }^{2}$ This shift was determined by the complexities and the high research costs involved in the newly emerging technological systems of the second industrial revolution such as chemicals, electricity, and steel. ${ }^{3}$ The search for innovations in these fields required access to bodies of new scientific knowledge, the integration of different technological skills, the utilization of expensive pieces of equipment, and long development times. All this clearly amounted to a major increase in the scale and scope of the resources underpinning inventive activities and brought about a major organizational transformation, with large firms and corporations

\footnotetext{
*Author Affiliations: Alessandro Nuvolari, Sant'Anna School of Advanced Studies; Michelangelo Vasta, University of Siena.

${ }^{1}$ We would like to thank Sara Pecchioli for outstanding research assistance and Michele Mannucci for granting us access to the historical library of Ufficio Tecnico Ing. A. Mannucci s.r.l located in Florence. We are particularly grateful to Lucio Barabesi, Chris Colvin, Giacomo Domini, Giovanni Federico, Gabriel Galvez-Behar, Renato Giannetti, Graeme Gooday, Anna Guagnini, Laura Magazzini, Petra Moser, Tom Nicholas, Roberto Renò, and Fabio Vanni for helpful comments and suggestions. The article has also benefited from the comments of three anonymous referees and of participants at the Economic History Society Annual Conference (York, 2013), the 7th World Congress of Cliometrics (Honolulu, 2013), the European Business History Association Conference (Uppsala, 2013), the European Historical Economics Society Conference (London, 2013), and the workshop on 'International diversity in patent cultures. A historical perspective' (Leeds, 2014).

${ }^{2}$ Schumpeter, Capitalism, pp. 131-4; Bernal, Science and industry, p. 151. Schumpeter's thesis on the demise of individual inventors was anticipated in Schumpeter, 'Instability', p. 384: '[I]n "trustified" capitalism ... [i]nnovation is . . . not any more embodied typically in new firms, but goes on, within the big units now existing, largely independently of individual persons'.

${ }^{3}$ Freeman and Louçã, As time goes by, pp. 220-56.
} 
establishing dedicated in-house research laboratories employing specialized teams of scientists and engineers. ${ }^{4}$

Lamoreaux and Sokoloff have shown that empirical evidence from US patent records provides support for this 'Schumpeterian' account. ${ }^{5}$ The patent data studied by Lamoreaux and Sokoloff show that, over the period 1870-1911, a growing share of patents were assigned at issue to large firms and other companies. In their view, this piece of evidence indicates that inventors were increasingly carrying out inventive activities either as firms' employees or by being involved in long-term collaborative relationships with firms. In a related paper, Lamoreaux, Sokoloff, and Sutthiphisal provide a more 'nuanced' picture by noting the co-existence of two alternative patterns of organization of invention. ${ }^{6}$ One, structured around the R\&D laboratories of large firms, was typical of the Middle Atlantic region and is fully consistent with the narrative outlined above. However, alongside this model it is possible to identify a second pattern of innovative activities characterized by smaller entrepreneurial dynamic firms, mostly located in New England. ${ }^{7}$

This 'Schumpeterian' tale of the rise of organized research was undoubtedly appealing since it was broadly consistent with the narratives of business historians and historians of technology who described the rise of the corporate economy in countries such as the US, Germany, and Britain. ${ }^{8}$ However, it did not command universal consensus. The most famous dissenting voice is probably the classic study by Jewkes, Sawers, and Stillerman. ${ }^{9}$ On the basis of evidence from detailed case studies, they claimed that the most important breakthrough innovations of the twentieth century were actually the outcome of the efforts of individual inventors. In their view, the bureaucratization of corporate laboratories produces a conformist approach to research which ultimately prevents the discovery of genuine radical innovations. ${ }^{10}$ As a result, there was no major shift in the 'sources of invention' from the nineteenth to the twentieth century and independent inventors have continued to provide the most important contribution to technological progress. ${ }^{11}$

Assessing the historical plausibility of the account by Jewkes, Sawers, and Stillerman is by no means straightforward. ${ }^{12}$ Their work is based on detailed historical descriptions of a selection of nineteenth- and twentieth-century macroinventions in different countries. Accordingly, it is hard to ascertain whether their sample of inventions may indeed be regarded as truly representative of historical trends in innovation both worldwide and in specific countries.

In two recent papers, Nicholas has attempted to shed new light on this issue by providing a systematic assessment of the contribution of independent inventors to

\footnotetext{
${ }^{4}$ von Tunzelmann, Technology, pp. 161-5; Freeman and Soete, Economics, pp. 80-4; Mowery and Rosenberg, Paths of innovation. For a detailed case study of the emergence of corporate research laboratories in the German chemical industry, see Meyer-Thurow, 'Industrialization of invention'.

${ }^{5}$ Lamoreaux and Sokoloff, 'Decline of the independent inventor'.

${ }^{6}$ Lamoreaux, Sokoloff, and Sutthiphisal, 'Reorganization of inventive activity'.

${ }^{7}$ On the rise of corporate intellectual property in the US, see Fisk, Working knowledge.

${ }^{8}$ Chandler, Scale and scope; Hounshell, 'Evolution of industrial research'.

${ }^{9}$ Jewkes, Sawers, and Stillerman, Sources of invention.

${ }^{10}$ For an insightful discussion of the role played by individual inventors in the generation of major technological breakthrough, see O'Brien, 'Micro foundations'.

${ }^{11}$ For a similar argument, see Hatfield, Inventor, pp. 40-7. For a more 'balanced' interpretation stressing the role of both independent and corporate inventors, see Schmookler, 'Inventors'.

${ }^{12}$ Jewkes et al., Sources of invention.
} 
technological progress using evidence from the patent records. ${ }^{13}$ Nicholas shows that in the US, Britain, and Japan, independent inventors continued to account for a very significant volume of inventive activity and, more importantly, for the generation of several high-quality innovations until the late 1930s, playing a vital role in the advancement of the technological frontier. In all these countries, despite significant differences in patent legislation, independent inventors could make use of relatively functioning 'markets for technologies' for reaping economic returns from their inventions, and they could specialize in inventive activities without becoming directly involved in commercialization and production. ${ }^{14}$

This article expands on this line of research by looking at the role played by independent inventors in Italy during the Liberal Age (1861-1913). It makes use of a new dataset of all Italian patents granted in five benchmark years. These data make it possible to examine closely the inventive output of individual inventors and firms, both domestic and foreign. ${ }^{15}$ The Italian case seems particularly promising for further engagement with this research question, for at least three reasons.

First, although Italy, in the period in question, was a 'latecomer industrializer', it was able autonomously to develop a number of significant breakthrough inventions including 'macroinventions' à la Mokyr: ${ }^{16}$ Ascanio Sobrero (1812-88), an academic chemist working in Turin, in 1847 discovered nitroglycerine; Antonio Pacinotti (1841-1912) in 1860 made a major contribution to the development of the electric dynamo; finally, and most notably, Guglielmo Marconi (1874-1937) pioneered the first successful long-distance radio transmission equipment. ${ }^{17}$ These achievements are probably explained by a long-term cultural heritage that allowed the country to remain connected with the shifts of the world technological frontier despite its relative economic backwardness. ${ }^{18}$ This historical phase in Italy also saw the rise and consolidation of a number of rather innovative large firms, moving along the technological trajectories of the second industrial revolution, such as Edison and Ansaldo. ${ }^{19}$ This dynamism at the micro level is confirmed by recent

\footnotetext{
${ }^{13}$ Nicholas, 'Role of independent invention'; idem, 'Independent invention during the rise of the corporate economy'. Other papers have recently examined the role played by independent inventors using patents: for Spain in the period 1820-1939, see Sáiz, 'Social networks'; and for Norway in the second half of the nineteenth century, see Basberg, 'Amateur or professional?'.

${ }^{14}$ For a thorough appraisal of the functioning of 'markets for technologies', see Arora, Fosfuri, and Gambardella, Markets for technology. For historical evidence on the consolidation of 'markets of technologies' in the US in the period we are considering here, see Lamoreaux and Sokoloff, 'Intermediaries'.

15 The use of patents as a proxy measure of innovation is a widespread practice both in the economics of innovation and in the historical literature. To be sure, it must be recognized that patents data are fraught with several limitations so that other proxy measures have also been introduced in order to assess the rate and direction of technical change (for the use of exhibition data at the World Fairs, see Moser, 'Patent laws'). However, on this point it is still worth quoting the seminal book by Schmookler, Invention, p. 56: 'We have a choice of using patent data cautiously and learning what we can from them or not using them and learning nothing about what they can teach us'. For a recent comprehensive survey on this issue, see Nagaoka, Motohashi, and Goto, 'Patent statistics'.

${ }^{16}$ Mokyr, Lever of riches, pp. 13-14.

${ }^{17}$ For a useful survey of the major scientific and technological developments in Italy during the Liberal Age, see Maiocchi, 'Ruolo delle scienze'.

${ }^{18}$ Giannetti, Tecnologia e sviluppo.

${ }^{19}$ The 'Italian' Edison company was able to build one of the first electric power stations in the world; see Guagnini, 'Bold leap'. Ansaldo, initially exploiting partnerships and licensing agreements with foreign firms, was active in several high tech sectors (for a technology history of Ansaldo, based on patent data, see Vasta, 'Innovazioni tecnologiche').
} 
estimates by Broadberry, Giordano, and Zollino, which show that over the period 1881-1911 Italy was able to narrow significantly the gap in industrial labour productivity with the UK. ${ }^{20}$

Second, the Italian case is also interesting in terms of the characteristics of its patent system. In particular, in terms of the costs of patenting, Italy was an intermediate case between the 'very expensive' British and German and the 'very cheap' American patent system. Since the cost of patents is an important factor shaping the incentives of independent invention, the Italian evidence seems to have the potential to shed some further light on this issue.

Third, it is worth noting that Italy, mainly due to the appeal of its market, was characterized by the widespread presence of foreign firms which operated in the most technologically advanced sectors. These firms conveyed intense technology flows which resulted in considerable patenting activity. Meanwhile, Italian firmsmostly small in size-were mainly focused in traditional sectors. Nevertheless, some Italian firms, through license agreements with large foreign companies, were often able to adapt advanced foreign technology to the local context. ${ }^{21}$

Overall, we find that the quality of the patents taken out by independent inventors in Italy was lower than that of corporate patents. Our suggested interpretation is that the phenomenon of independent invention in Italy was rather different from the cases of the UK and the US studied by Nicholas. In these countries, independent inventors were relatively skilled individuals who were able to generate high-quality inventions, perhaps also with a view to their commercialization using 'markets for technologies'. On the contrary, in the Italian case, independent inventors could provide an important contribution to technological change, but the quality of their patents was significantly lower than that of firms and of foreign patentees. We shall argue that this phenomenon can be ascribed to the backwardness of the Italian human capital stock, which, at the time, presented a low level of literacy-with remarkable regional disparities - a limited level of general schooling, and a scarce and scattered diffusion of formalized technical competencies. ${ }^{22}$

This article proceeds as follows. Section I provides a sketch of the Italian patent system in comparative perspective. Section II describes the historical sources and the methods used for the construction of the dataset. Section III presents a statistical overview of the data, examining the relative shares of independent, corporate, domestic, and foreign inventions and their evolution over time, across industries, and across different locations. Using renewal data as a proxy for the value of patents, section IV provides a systematic comparison of the relative quality of independent and corporate patents. Section V concludes.

The Kingdom of Sardinia (which, despite the name, consisted mainly of Piedmont and Liguria) played a major role in the process of Italian political unification

\footnotetext{
${ }^{20}$ Broadberry, Giordano, and Zollino, 'Productivity'.

${ }^{21}$ For a recent assessment of the role of foreign technology in Italy, see Barbiellini Amidei, Cantwell, and Spadavecchia, 'Innovation'. On the issue of firms' size, see Amatori, Bugamelli, and Colli, 'Technology'.

${ }^{22}$ On human capital in Italy, see A'Hearn, Auria, and Vecchi, 'Istruzione'; Felice and Vasta, 'Passive modernization?'. For a broad comparative perspective with other countries, see: for literacy rates, Cipolla, Literacy and development, passim; and Nuvolari and Vasta, 'Ghost in the attic?', tab. 1; for educational attainments, Morrisson and Murtin, 'Century of education'; and for stocks of engineers, Vasta, Innovazione tecnologica, p. 250.
} 
culminating in 1861 with the proclamation of Vittorio Emanuele II as king of Italy. Like many other laws and regulations, the Piedmontese patent system was extended to the 'new' country. ${ }^{23}$ The original version of this patent law (inspired by the French and Belgian examples of 1844 and 1854) had been introduced in Piedmont in 1855. In a nutshell, the main features of the Italian patent system were the following. It was a registration system and, accordingly, there was no examination of the actual novelty of the invention patented. In practice, this meant that controversies about the novelty of patents were to be settled by means of court cases. In the Italian system, patents could be registered either in the name of individual inventors or in the name of firms. ${ }^{24}$ This peculiarity of the Italian patent law allows us to make an immediate direct assessment of whether a patent is to be ascribed to an independent inventor or to a firm.

Another important feature of patent systems is the cost of taking out and maintaining a patent. These costs affect the choice of an inventor on whether to protect his invention, and for how long. If a patent system is very expensive, fewer inventors will have recourse to patent protection and, at the same time, it is likely that patent protection will be used mostly by firms or independent inventors with sufficient financial resources. Furthermore, in an expensive system, it is unlikely that inventions that are expected to generate limited economic returns will be patented (because the profits of the invention may not cover the full costs of patent protection).

In Italy the system was extremely flexible: an inventor could register a patent for the duration of one to 15 years according to his own choice. There was an initial fee that was proportional to the number of years for which the patent was requested (10 Italian lire for one year, 20 lire for two years, and so on, up to 150 lire for 15 years). In addition, it was necessary to pay an annual renewal fee for maintaining the patent. This fee increased over time: 40 lire for the first three years, 65 lire from the fourth to the sixth year, 90 lire for the seventh up to the ninth year, 115 lire for the tenth to the twelfth year, and 140 lire for the last three years. It is worth noting that the Gazzetta Ufficiale del Regno d'Italia regularly published the entire list of patents that had expired due to non-payment of the renewal fees. Furthermore, the law also allowed the possibility of 'extending' the duration of a patent initially taken for a shorter period. In order to do this, the inventor had to apply for an attestato di prolungamento. This cost 40 lire plus all the other fees required for a normal patent of the same duration. Hence, since prolungamento involved an extra cost of 40 lire, when the inventor was sure about the prospects of his invention, it was more convenient to take out a patent for the desired duration immediately. However, when the prospects for the invention were uncertain, the possibility of taking prolungamento gave the system a further degree of flexibility. Finally, it was also possible to extend the scope of a patent, for example, by adding improvements and other features to an original patent application. This was done by applying for an attestato completivo that cost a fixed fee of 20 lire.

Unfortunately, because of subtle differences in the structure of patent fees and in the actual enforcement of patent protection in different legislations, it is not straightforward to compare precisely the costs of patenting in different countries.

${ }^{23}$ Law no. 1657, 31 Jan. 1864.

${ }^{24}$ Article 27 of the Regolamento of the 1864 Law stated explicitly that the application for a patent could be submitted both by individuals and by corporations or other organizations; Franchi, ed., Codici e leggi. 


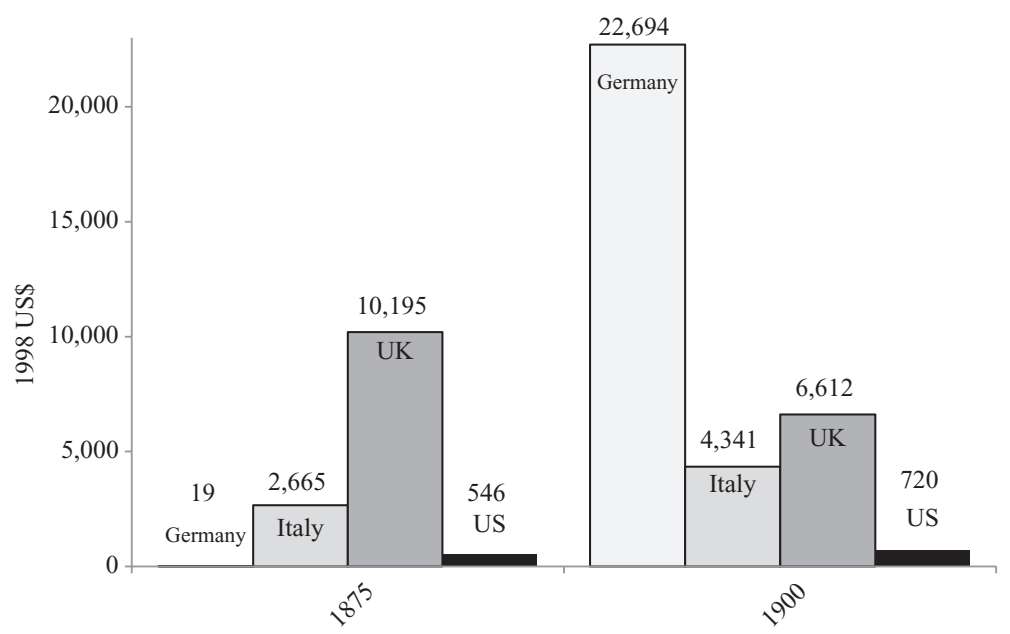

Figure 1. Cost of patenting (to maintain a patent for the full legal term) in different countries, 1998 US\$

Source: Lerner, '150 years', tab. 3, pp. 33-4.

To these difficulties, we should add the necessity of converting patent fees to a common currency, properly taking into account variations in the price level and properly discounting the patent fees that had to be paid at different times.

Nevertheless, figure 1 reports the estimates of the costs of patenting (in 1998 US\$) in different systems reconstructed by Lerner. ${ }^{25}$ Figure 1 shows that the most expensive systems around 1900 were the British and German ones. On the other hand, in comparative perspective, the US system was cheap and affordable. Interestingly enough, the Italian system has an intermediate position between these two models.

The renewal fee structures for Britain and Germany have been discussed recently by Nicholas and by Streb, Baten, and Yin, respectively. ${ }^{26}$ Figure 2 compares the structure of renewal fees in Italy, the UK, and Germany. The yearly fees have been measured in relation to the average weekly wages of workers in the engineering sector. Overall, this normalized measure confirms that, except for the initial year, the costs of maintaining a patent was systematically lower in Italy than in Germany and the UK. The last histogram on the right reports the total amount of the fees paid throughout the patent life. Again, Italy appears to offer considerably cheaper fees in comparative perspective. It is worth noting that the most expensive annual renewal fees (those for years 13,14, and 15) are lower than the cost in year 1. For this reason, it seems very unlikely that an inventor who had been able to enter the Italian system (paying the costs in year 1) was later on impaired in his renewal behaviour by credit constraints. ${ }^{27}$ Of course, this argument does not exclude the possibility that some independent inventors may not have been able to

\footnotetext{
${ }^{25}$ Lerner, ' 150 years'. Note that the first national patent law in Germany was introduced in 1877.

${ }^{26}$ Nicholas, 'Cheaper patents'; Streb, Baten, and Yin, 'Technological and geographical knowledge spillover', pp. 349-57.

${ }^{27}$ Interestingly enough, this peculiarity of the Italian system supports the use of renewal data as an indicator of the quality of patents.
} 


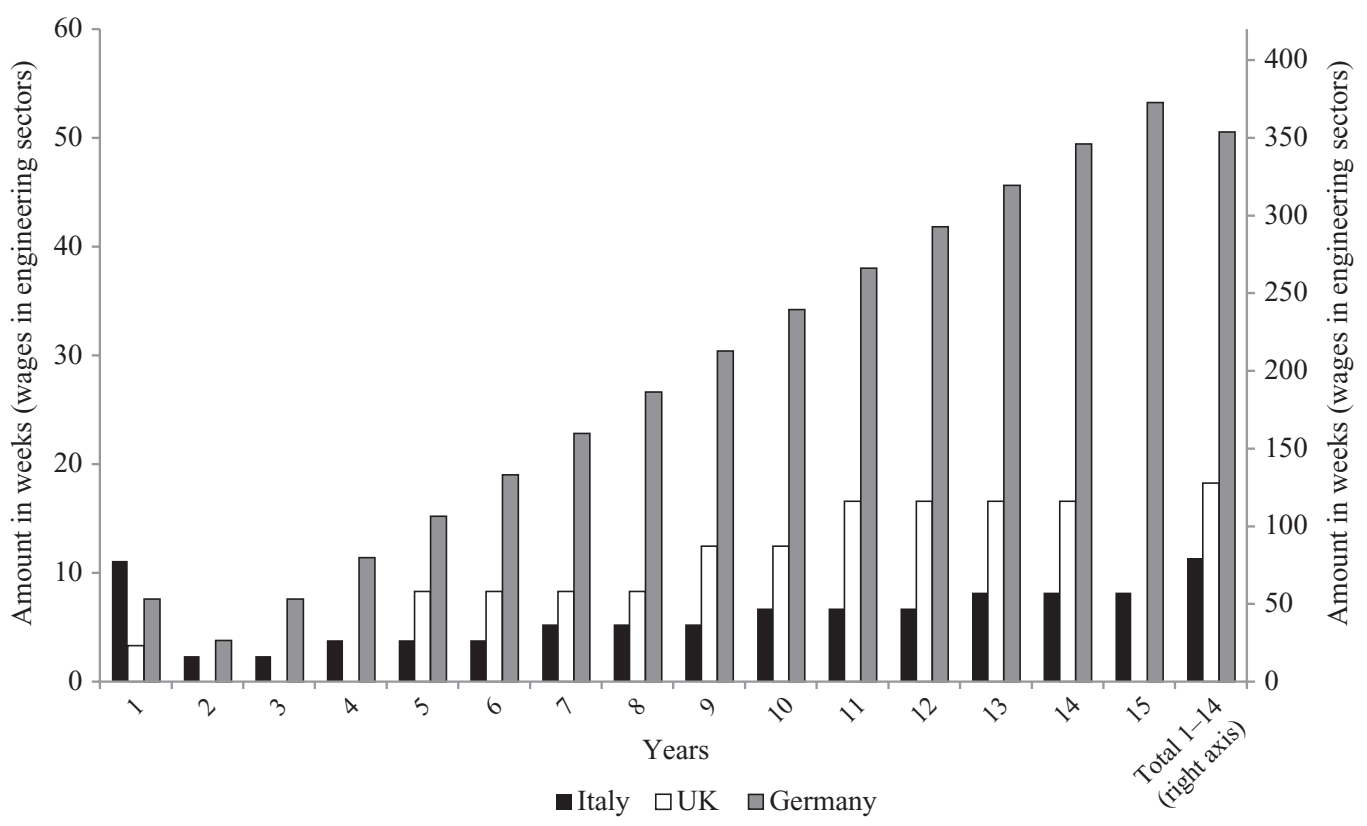

Figure 2. Annual renewal fees of patenting in Italy, the UK, and Germany, 1880s Note: Years $1-15$ on the left axis; total period 1-14 on the right axis.

Sources: Authors' elaboration based on patent renewals data for the UK: Nicholas, 'Cheaper patents', p. 338; Germany: Streb et al., 'Technological and geographical knowledge spillover'; Italy: Italian Law no. 1657, 31 Jan. 1864; and on wages from Scholliers and Zamagni, eds., Labour's reward, pp. 210-19 (Germany), 231-3 (Italy), 258-66 (the UK).

access the patent system because of credit constraints. Nevertheless, these inventors are not included in our sample and consequently they do not affect the results of our work as far as patenting behaviour is concerned.

Sokoloff and Khan have argued that the US system, by being relatively cheap and accessible, provided a large share of the population with the opportunity to exploit their inventive activities by means of patent protection (the 'democratization of invention'). ${ }^{28}$ Figure 2 suggests that the Italian system was also probably relatively affordable to individuals (even to those with limited financial resources). For example, according to Bosio, an authoritative legal scholar of the time, the ease of access to the system for inventors with limited financial resources was an explicit rationale accounting for the peculiar renewal fee structure of the Italian system. ${ }^{29}$

Having discussed the Italian patent legislation, it is now worth examining trends in patenting behaviour across countries. Figure 3 shows the number of patents per million inhabitants in different systems during the period. The critical effect of legislation (and in particular of patent fees) on patenting behaviour is illustrated by the sharp discontinuity of the British series in 1883 (when the cost of patenting was drastically reduced). Even if Italy at the time was a latecomer country, its volume of patenting activity was not far off that of a leading country of the second industrial revolution such as Germany. Of course, in drawing this comparison, it

\footnotetext{
${ }^{28}$ Sokoloff and Khan, 'Democratization of invention'; Khan, Democratization of invention, pp. 49-65.

${ }^{29}$ Bosio, Privative industriali, pp. 168-70.
} 


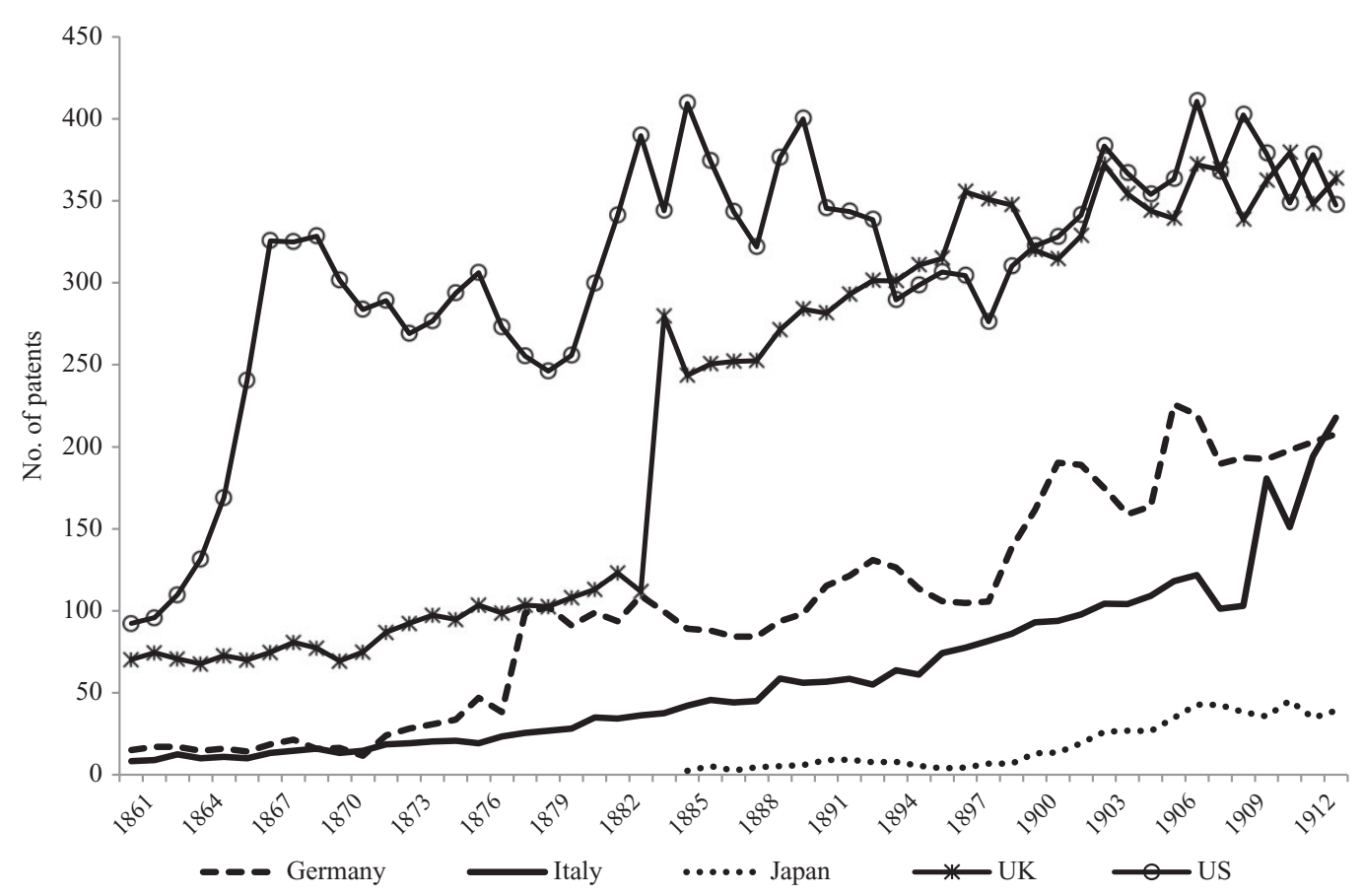

Figure 3. Patents granted in selected countries per million inhabitants, 1861-1913

Sources: Authors' elaboration, 1861-82: Khan, 'Economic history'; 1883-1913: WIPO, 'Statistics database'; data for Italy from MAIC, Bollettino delle privative industriali del Regno d'Italia, 1864-85, 1886-93; idem, Elenco degli attestati di privativa industrial; idem, Bollettino della proprietà intellettuale.

is important to keep in mind the significantly lower costs of the Italian system presented in figures 1 and 2 .

The trends presented in figure 3 should not be regarded as a proxy for the innovation performances of different countries. Technology gaps across countries are instead better captured by the time series presented in figure 4, which shows the number of patents granted in the US to foreign residents, normalized by population. This indeed is a proxy for national technological performance which is frequently used in literature on the economics of innovation. ${ }^{30}$ In figure 4, Germany and the UK are clearly the two leading countries, and Italy is at a significantly lower level, although there is some 'catching up' during the period, ${ }^{31}$ while Japan is consistently at the bottom.

Table 1 shows the share of foreign patents in different countries. This may be regarded as a proxy for the 'openness' of national patent systems. The table shows that the system with the lowest share of foreign patents is the US one. On the other hand, the Italian system is definitively the most open. This is remarkable because, as noted by Bilir, Moser, and Talis, before the Paris Convention of 1883, in most countries patenting abroad was severely constrained by procedural difficulties and discriminatory clauses. ${ }^{32}$ Overall, the large share of foreign patents in Italy can

\footnotetext{
${ }^{30}$ See, for instance, Freeman and Soete, Economics, pp. 112-21.

31 This successful catching-up phase is also apparent from Italy's performance in different European patent systems, as shown by Barbiellini Amidei et al., 'Innovation', fig. 14.1, p. 386.

${ }^{32}$ Bilir, Moser, and Talis, 'Treaties'.
} 


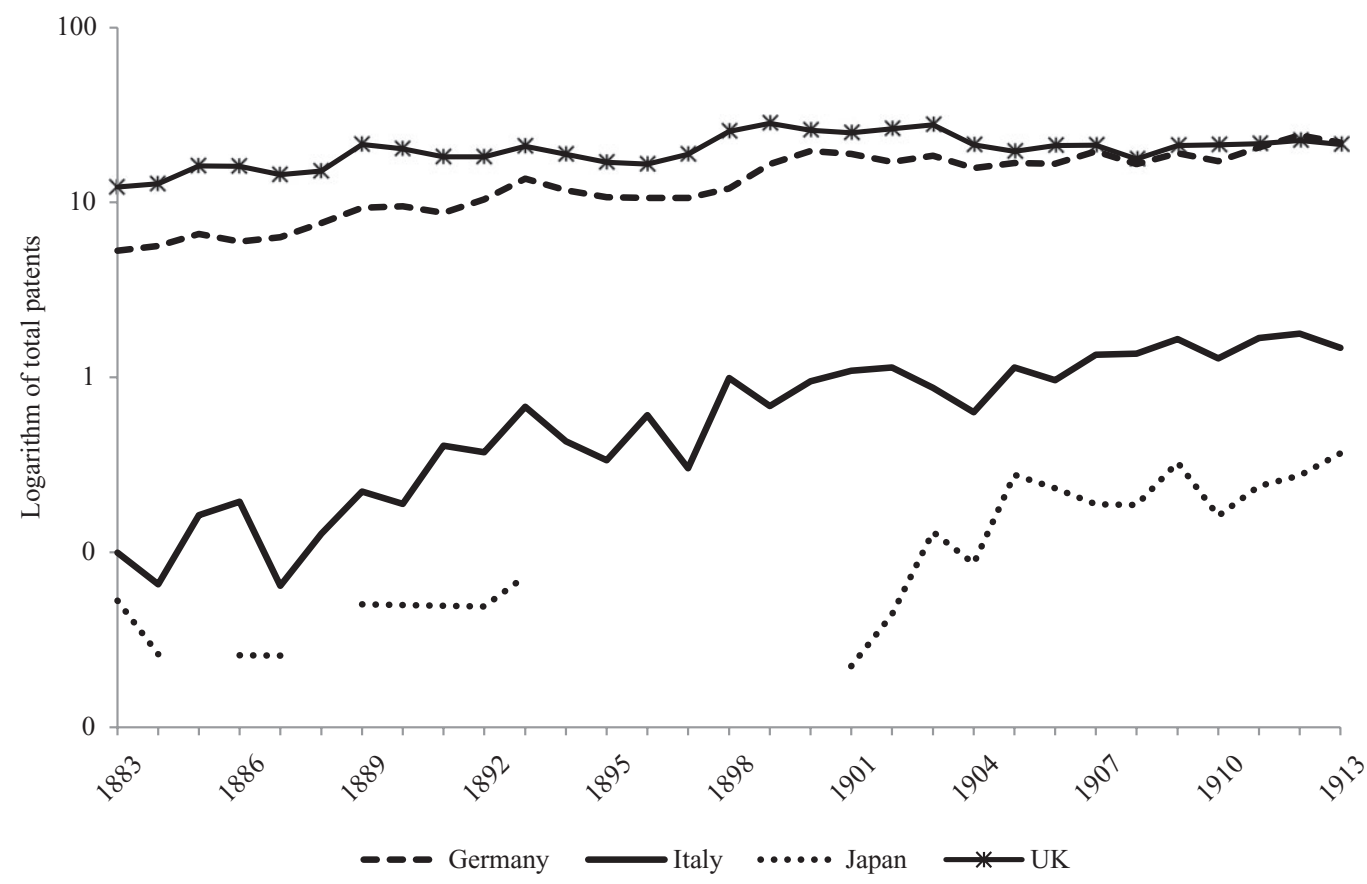

Figure 4. Patents granted in the US to foreign residents per million inhabitants, 1883-1913

Sources: Authors' elaboration on USPTO, Technology Assessment, and on Maddison, 'Statistics'.

Table 1. Degree of openness (\% of non-residents in total) of patent systems, 1871-1914

\begin{tabular}{lcccc}
\hline Countries & $1864-5$ & 1880 & 1901 & 1914 \\
\hline Germany & & 31.1 & 37.1 & 30.1 \\
Italy & 50.7 & 64.9 & 64.9 & 61.5 \\
UK & & & 53.2 & \\
US & & & 13.3 & 11.5 \\
\hline
\end{tabular}

Note: For Germany, 1883 instead of 1880.

Sources: Authors' elaboration on WIPO, 'Statistics database'; data for Italy from MAIC, Bollettino delle privative industriali del Regno d'Italia, 1864-85, 1886-93; idem, Elenco degli attestati di privativa industrial; idem, Bollettino della proprietà intellettuale.

probably be ascribed to the combined effect of the low costs of patenting, the technological backwardness of the country, and its size in terms of population, which made Italy an appealing market.

\section{II}

To study the phenomenon of independent invention in Italy by means of systematic quantitative evidence, we have built a new dataset comprising all 10,124 patents granted in Italy in five benchmark years: 1864-5 (520 patents), 1881 (941 
patents), 1891 (1,618 patents), 1902 (2,987 patents), and 1911 (4,058 patents). ${ }^{33}$ The choice of these benchmarks has been dictated by our concern of ensuring an even coverage of the entire Liberal Age period. ${ }^{34}$ The historical sources of these data are the Italian official serial publications of the Ministero di Agricoltura, Industria e Commercio (MAIC). For each patent we have collected the following information: the date on which the patent was applied for (data di deposito); the date on which the patent was granted (data di rilascio); the official patent number; the name(s) of the patentee(s) (this may be an individual inventor or a firm); ${ }^{35}$ the city (or cities) of residence of the patentee(s); the initial duration of the patent; the number and duration of the extensions (prolungamento) of the patent; ${ }^{36}$ a short description of the invention; the technological category in which the patent was classified by the office; other information about the life of the patent (such as changes in the number and city of residence of patentees following a prolungamento or completivo, or changes in the patent specification); and, for the benchmark years 1881,1891 , and 1902, we also have information about the date on which the patent expired because the patentee did not pay the renewal fees. This allows us to determine the 'real' duration of the patent. ${ }^{37}$ The information on the expiration of patents due to non-payment of renewal fees was collected by examining the complete series of the Gazzetta Ufficiale del Regno d'Italia for 15 years after each benchmark year.

In addition, we have reclassified all patents from the original administrative technological classes to a new classification system, chiefly inspired by the International Standard Industrial Classification (ISIC) categories.

\section{III}

In figure 5 we compare the evolution of independent inventions in Italy with those of other major industrializing countries (the US, Britain, and Japan) using the data compiled by Nicholas. ${ }^{38}$ We have also added data from Spain taken from Sáiz. ${ }^{39}$ Figure 5 shows that the share of independent inventions among total patents over

\footnotetext{
${ }^{33}$ Given the small number of patents registered in the early years after unification, we decided to consider an initial benchmark of two years, 1864 and 1865 .

${ }^{34}$ We have attempted to choose benchmarks corresponding to the census years, with the exception of $1864-5$ (the first years of the MAIC publication) and of 1902, since in that year there is a new official publication of MAIC, which is more accurate in reporting patent descriptions and durations.

${ }^{35}$ By following patents over their lifespans, we have identified 106 patents that were initially granted to independent inventors and some years later, when prolonged, were attributed to firms. In this case, we have decided to classify these patents as corporate. Interestingly enough, 12 of these patents were granted to Thomas A. Edison and prolonged a few years later in the name of Compagnie Continentale Edison Societé Anonyme. In fact, for these 12 patents we were able to trace an announcement of the property transfer from Edison to the Compagnie Continentale Edison published in the Gazzetta Ufficiale del Regno d'Italia, no. 58, 11 March 1885, p. 1146 (we thank Anna Guagnini for bringing this reference to our attention).

${ }^{36}$ For each cohort, we have thoroughly checked the possible existence of extensions (prolungamento) in the official publications of the following 15 years.

${ }^{37}$ It was not possible to retrieve this information for the 1864-5 cohort because the Gazzetta Ufficiale del Regno d'Italia provided the full list of expiring patents only starting from the last trimester of 1867 . At the same time, it was not possible to gather information for the 1911 cohort because from 1915 the Gazzetta no longer published the list of expired patents.

${ }^{38}$ Nicholas, 'Independent invention during the rise of the corporate economy', p. 1003. We would like to thank Tom Nicholas for providing us with the detailed data on independent inventions in the US, the UK, and Japan used in fig. 5 .

${ }^{39}$ Sáiz, 'Social networks'. 


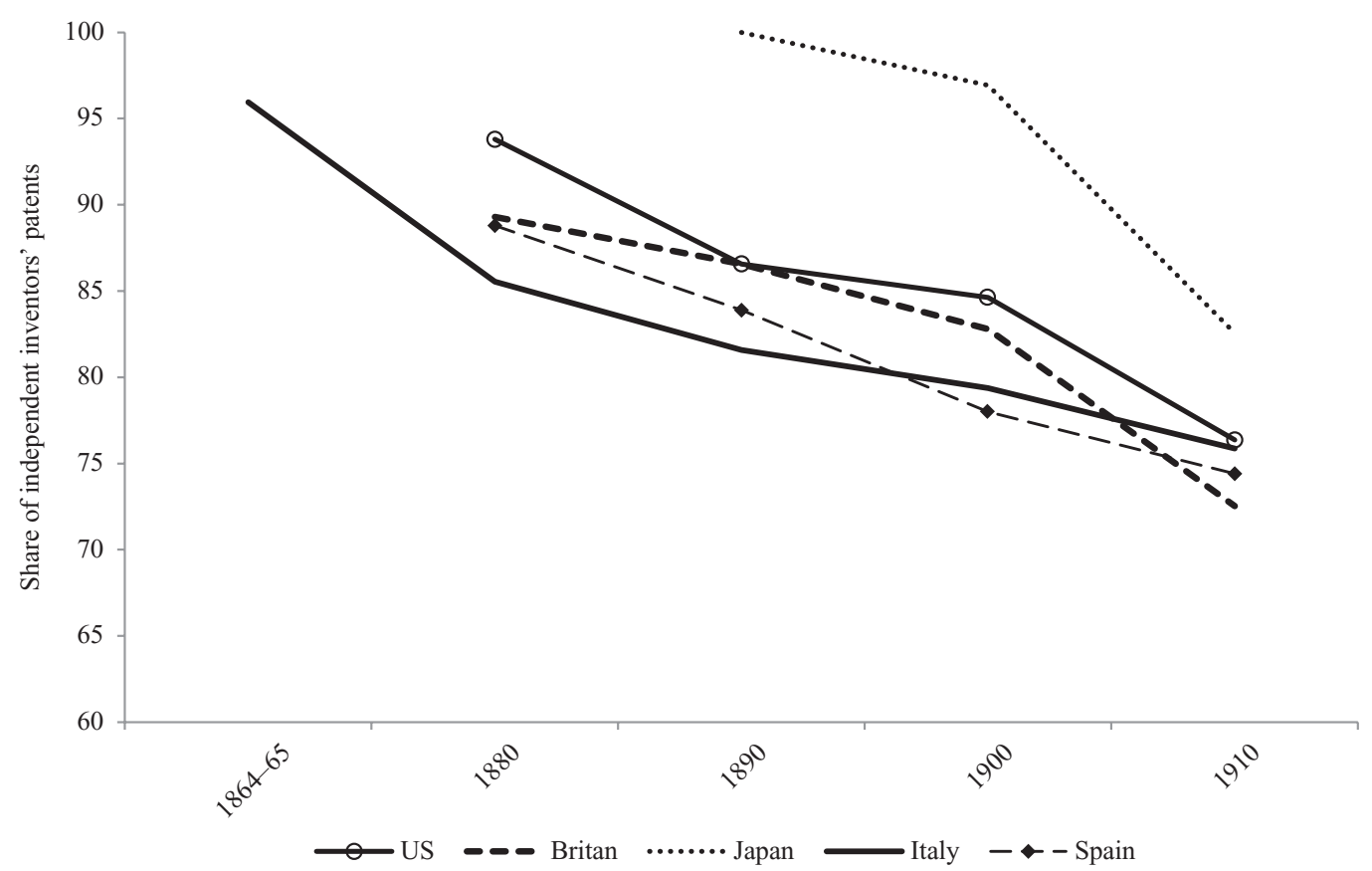

Figure 5. Share of independent inventors in different countries for benchmark years Note: For Italy the benchmark years are: 1881, 1891, 1902, and 1911; for Spain, data correspond to 10 years' average centred on 1884, 1894, 1904, and 1914.

Sources: For the US, Britain, and Japan, authors' elaboration on data kindly provided by Nicholas, 'Independent invention during the rise of the corporate economy', fig. 3, p. 1003; for Spain, on Sáiz, 'Social networks', tab. 1, p. 357; and for Italy, on MAIC, Bollettino delle privative industriali del Regno d'Italia, 1864-85, 1886-93; idem, Elenco degli attestati di privativa industrial; idem, Bollettino della proprietà intellettuale.

the period $1864-1914$ is characterized by a decreasing and concomitant trend in all countries. Interestingly enough, the levels of the shares also appear to be remarkably similar for the US, Britain, Spain, and Italy, exhibiting a decline from a share of about $90-5$ per cent around 1880 to a share of about 85 per cent in 1900 , and finally declining to about 70-5 per cent during the 1910s. Japan is also characterized by a decreasing trend, but the major decline in the share of independent inventions occurs in a later period: from 1900 to 1910 .

Overall, figure 5 suggests that a significant shift towards the growth of corporate patents, possibly consistent with Bernal's 'industrialization of invention', was actually taking place across all countries. ${ }^{40}$ On reflection, this is remarkable since we are considering countries characterized by different patent laws and at different stages of development (two first-comers, the UK and the US; and three latecomers, Italy, Japan, and Spain). However, it is worth noting that in the 1910s in all the countries considered, the share of independent inventors was still almost three-quarters of the total. Still, these trends are fully consistent with the 'Schumpeterian' tale of the rise of corporate inventions previously discussed in the introduction.

Before proceeding further, a word of caution is in order: it should be taken into account that, as noted by Schmookler, it is not always straightforward to determine

\footnotetext{
${ }^{40}$ Bernal, Science and industry, p. 151.
} 
Table 2. Italian patent sample (descriptive statistics)

\begin{tabular}{lccccc}
\hline & $1864-5$ & 1881 & 1891 & 1902 & 1911 \\
\hline Type of patentee & & & & & \\
$\quad$ Total & 520 & 941 & 1,618 & 2,987 & 4,058 \\
Firm (\%) & 4.0 & 14.5 & 18.4 & 20.6 & 24.1 \\
Independent (\%) & 96.0 & 85.5 & 81.6 & 79.4 & 75.9 \\
Localization & & & & & \\
Foreign & 263 & 603 & 1,132 & 1,965 & 2,264 \\
Firm (\%) & 3.0 & 15.1 & 18.8 & 25.8 & 31.9 \\
Independent (\%) & 97.0 & 84.9 & 81.2 & 74.2 & 68.1 \\
Italy (\%) & 257 & 338 & 486 & 1,022 & 1,794 \\
Firm (\%) & 5.1 & 13.3 & 17.5 & 10.8 & 14.3 \\
Independent (\%) & 94.9 & 86.7 & 82.5 & 89.2 & 85.7 \\
Industrial triangle cities (Genoa, Milan, and & 151 & 176 & 233 & 501 & 990 \\
$\quad$ Turin) & & & & & \\
Firm (\%) & 6.0 & 18.8 & 25.3 & 14.2 & 18.1 \\
Independent (\%) & 94.0 & 81.3 & 74.7 & 85.8 & 81.9 \\
Average 'scheduled' length (years) & & & & & \\
Total & 6.8 & 6.2 & 7.3 & 6.3 & 5.6 \\
Firm & 7.5 & 8.3 & 9.0 & 8.7 & 8.1 \\
Independent & 6.7 & 5.8 & 6.8 & 5.6 & 4.7 \\
Foreign & 7.7 & 7.1 & 8.4 & 7.6 & 6.7 \\
Italy & 5.8 & 4.5 & 4.6 & 3.8 & 4.1 \\
\% of patents prolonged (excluding patents with & & & & & \\
$\quad$ original length = 15) & & & & & \\
Total & 10.7 & 17.9 & 17.5 & 23.8 & 24.1 \\
Firm & 22.2 & 39.7 & 27.6 & 36.2 & 38.1 \\
Independent & 10.2 & 14.4 & 15.5 & 21.0 & 20.0 \\
Foreign & 11.9 & 19.8 & 15.3 & 27.1 & 25.2 \\
Italy & 9.5 & 14.7 & 21.4 & 18.3 & 22.7 \\
\hline &
\end{tabular}

Sources: MAIC, Bollettino delle privative industriali del Regno d'Italia, 1864-85, 1886-93; idem, Elenco degli attestati di privativa industrial; idem, Bollettino della proprietà intellettuale.

whether a patent is to be ascribed to a firm or to an individual. ${ }^{41}$ It is possible that some of the patents assigned to corporations actually cover the inventions of individuals (when, for example, companies have entered into agreements with individuals before the granting of the patent). In the historical context considered here, this is not very likely, except in the case of the US. On the other hand, it is also possible that patents formally granted to individuals actually cover the formalized inventive activities taking place inside companies. This is probably a more serious source of error for the period considered here. For this reason, as argued earlier by Nicholas, the data presented in figure 5 are to be regarded more as approximations rather than exact figures. ${ }^{42}$

Table 2 contains descriptive statistics of the patent dataset that we have constructed. The first panel of the table simply shows the total number of patents and the share of independent inventors, which decreases throughout the period. The second panel gives information about the localization of the patentees. Consistent with our earlier observations on the degree of openness of the Italian system, we see that in all benchmark years the majority of patents were granted to foreign inventors. In 1891 they reached a peak amounting to more than two times the Italian ones. In particular, it is also worth noting that, for the two last benchmark

${ }^{41}$ Schmookler, Invention, pp. 25-6.

${ }^{42}$ Nicholas, 'Independent invention during the rise of the corporate economy', pp. 1001-3. 
years, the shares of patents granted to firms were considerably higher for foreign (25.8 per cent for 1902 and 31.9 per cent for 1911) than for Italian (respectively 10.8 per cent and 14.3 per cent) residents. Moreover, it emerges that about half of the patents granted to Italian residents were taken by inventors located in the 'industrial triangle' (the nearby provinces of Genoa, Milan, and Turin, situated in the north-west of the country), which was the cradle of the Italian industrialization process.

The third panel of table 2 examines the average 'scheduled' length of patents, which takes also into account the extensions (prolungamento) granted to each single patent. There are two rather clear patterns: first, the average length of patents granted to firms is systematically higher than that of individuals; and second, the average length of foreign patents is considerably higher than that of Italian ones. The last panel considers the behaviour of patentees with respect to the extension of the patent using prolungamento. The share of prolonged patents ranges between one-tenth in 1864-5 and one-fourth in 1911. The two categories of patentees that made most intensive use of extensions are firms and, at a somewhat lower level, foreign inventors.

In order to provide a better illustration of the localization of inventive activity, in figure 6 we present a set of maps showing the geographical distribution of patents registered by Italian residents throughout the period. There is a rather clear-cut divide, with the distribution strongly concentrated in the northern and in the central areas of the country. The 'industrial triangle' is to some extent already delineated in the first benchmark year, and it becomes clearly visible from 1881 . In the later years, this centralization is definitely much more apparent. Moreover, it is also clear that from 1891 Roma emerges as a province with a strong density of patenting, possibly because of its administrative role as the capital of the kingdom.

In order to study the sectoral distribution of patents, we have classified all patents according to 14 industrial classes. Table 3 shows that patenting activity was concentrated in three main fields, corresponding to electricity, steam engines, and transport. In all benchmark years these three industries together had a share of at least one-third of total patents. If we limit our attention to the two major technologies of the second industrial revolution, chemicals and electricity, it is interesting to see the contrast between the relatively large share of electricity patents in comparison with the limited share of chemicals patents. ${ }^{43}$ These patterns are consistent with historical accounts that have remarked on the relative success of the Italian electricity industry and the sluggish evolution of the chemical industry.

We have also identified a sub-set of patents directly related to the main 'macroinventions' of this period, comprising both the technological systems of the first industrial revolution (such as steam power and machine tools) and the emerging new technologies of the second industrial revolution (chemicals, steel, and electricity). These categories are indicated in table 3 with the superscript a. We have considered this particular set of patents as covering inventions with a significant degree of technological 'sophistication' and, accordingly, we call this category 'high tech' patents. We have also regarded as 'high tech' patents those related to the

\footnotetext{
${ }^{43}$ See Giannetti, Tecnologia e sviluppo, pp. 101-12. For a more extensive discussion of inventive activities in chemicals and electricity based on patent data, see Vasta, Innovazione tecnologica, pp. 129-210.
} 
1864-65

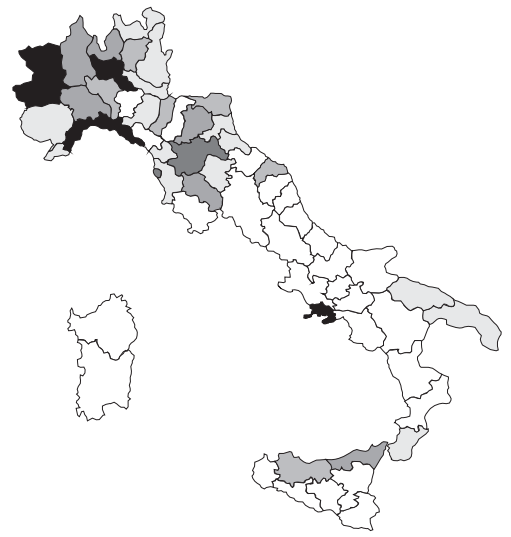

1891

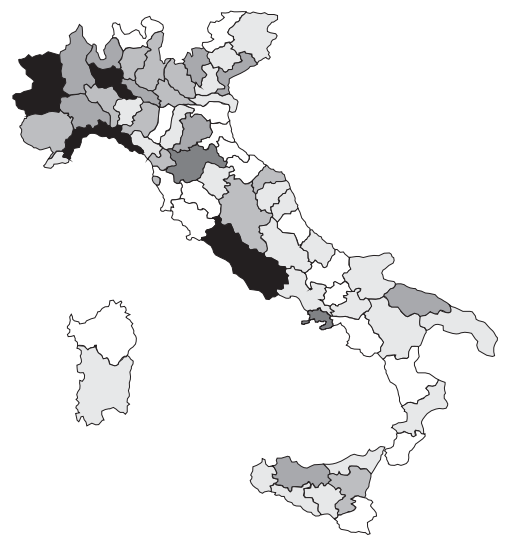

1911

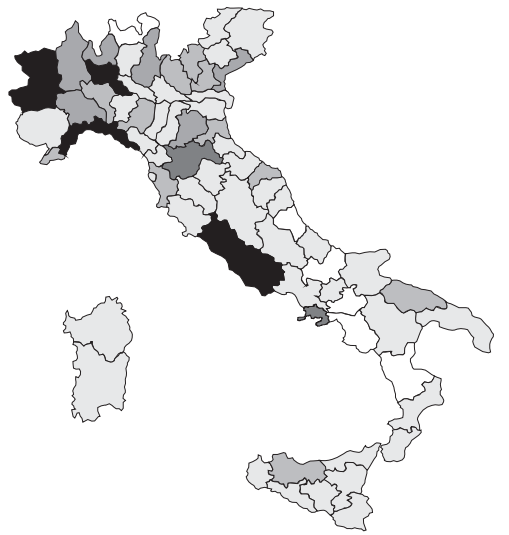

1881

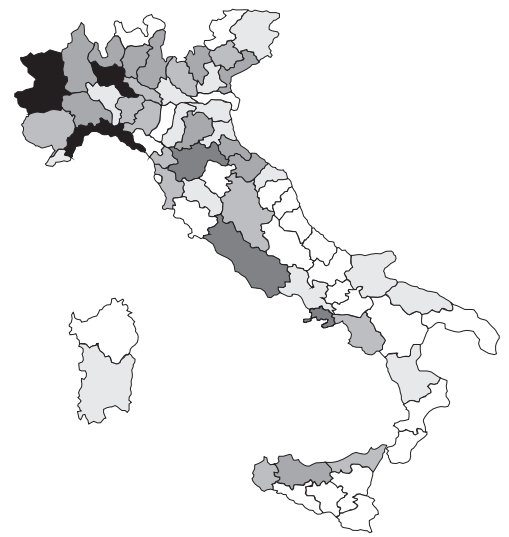

1902

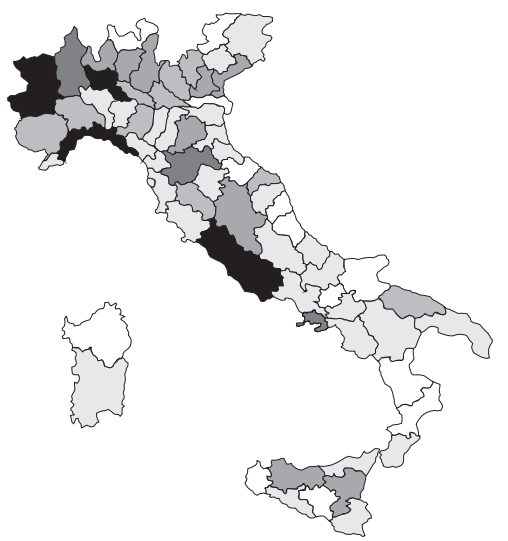

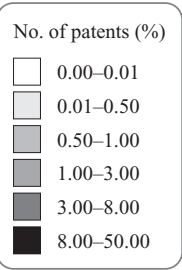

Figure 6. Geographical distribution of patents in Italy for benchmark years (share in total per province)

Sources: MAIC, Bollettino delle privative industriali del Regno d'Italia, 1864-85, 1886-93; idem, Elenco degli attestati di privativa industrial; idem, Bollettino della proprietà intellettuale. 
Table 3. Distribution of patents across industries

\begin{tabular}{|c|c|c|c|c|c|}
\hline & $1864-5$ & 1881 & 1891 & 1902 & 1911 \\
\hline \multicolumn{6}{|l|}{ Distribution (\%) of patents across industries } \\
\hline Agriculture & 3.3 & 6.6 & 5.6 & 3.3 & 2.9 \\
\hline Chemicals $^{a}$ & 8.5 & 6.8 & 5.5 & 5.8 & 4.7 \\
\hline Construction and construction materials & 7.1 & 3.9 & 5.7 & 6.3 & 7.7 \\
\hline Electricity $^{a}$ & 12.1 & 13.5 & 14.9 & 19.3 & 14.8 \\
\hline Food and beverages & 6.0 & 7.7 & 3.6 & 3.7 & 1.8 \\
\hline Machine tools, machinery, components, and metalworking ${ }^{a}$ & 19.4 & 3.8 & 3.2 & 4.2 & 4.2 \\
\hline Steam engines ${ }^{a}$ & & 8.0 & 10.1 & 11.0 & 14.2 \\
\hline Mining & 4.0 & 2.8 & 3.5 & 2.5 & 1.6 \\
\hline Other manufactures & 6.0 & 15.3 & 14.1 & 7.2 & 9.2 \\
\hline Paper and printing & 4.8 & 3.5 & 3.2 & 4.2 & 3.8 \\
\hline Scientific instruments & 2.7 & 7.7 & 4.3 & 6.2 & 6.4 \\
\hline Textiles, apparel, and leather & 7.3 & 8.2 & 9.8 & 10.5 & 8.2 \\
\hline Transport & 11.9 & 8.9 & 10.9 & 12.3 & 18.0 \\
\hline Weapons $^{a}$ & 6.9 & 3.4 & 5.8 & 3.6 & 2.5 \\
\hline Total & 100.0 & 100.0 & 100.0 & 100.0 & 100.0 \\
\hline High-tech patents & 46.9 & 35.5 & 39.4 & 43.9 & 40.4 \\
\hline$\%$ of high-tech patents granted to firms & 9.5 & 41.9 & 49.3 & 52.9 & 51.9 \\
\hline$\%$ of high-tech patents granted to independent inventors & 48.5 & 34.4 & 37.2 & 41.6 & 36.7 \\
\hline
\end{tabular}

Note: $a$ indicates high-tech patents.

In 1864-5 patents on steam engines and machine tools are counted together.

Sources: MAIC, Bollettino delle privative industriali del Regno d'Italia, 1864-85, 1886-93; idem, Elenco degli attestati di privativa industrial; idem, Bollettino della proprietà intellettuale.

technologies of the first industrial revolution, to take into account Italy's status as a latecomer country. ${ }^{44}$ Overall, the share of these 'high tech' patents is about 40 per cent and is fairly stable throughout the period. It should be noted that independent inventors seem to have been rather active in these technological fields.

\section{IV}

In his contributions, Nicholas adopts the number of citations in the US as the main indicator of the 'quality' of a patent. ${ }^{45} \mathrm{In}$ the economics of innovation literature, both citations and renewal data have been used extensively as proxies for the quality of patents. ${ }^{46}$ The intuition behind the use of citations is that patents covering important inventions will receive many citations in follow-up patents. The logic of using the renewal behaviour is the idea that inventors will pay the renewal fees only as long as the economic returns of the patent exceed the costs of maintaining it. Each of the proxies has both advantages and disadvantages. It is unlikely that an Italian patent would be cited in US patent applications because

\footnotetext{
${ }^{44}$ Fenoaltea, Reinterpretation, pp. 233-5, considers the industrial expansion of the Liberal Age in Italy as based on a peculiar combination of the technological trajectories of the first and of the second industrial revolution. Vasta, 'Largest 200 manufacturing firms', and Giannetti and Vasta, 'Big business', pp. 42-8, point out that even the top 200 Italian joint-stock companies by assets were mostly active in the sectors of the first industrial revolution up to the 1920 s.

${ }^{45}$ Nicholas, 'Role of independent invention'; idem, 'Independent invention during the rise of the corporate economy'.

${ }^{46}$ On patent citations as an indicator of patent quality, see Trajtenberg, 'Penny'; Moser, Ohmstedt, and Rhode, 'Patent citations'. On patent renewals, see Schankerman and Pakes, 'Estimates'; Griliches, 'Patent statistics', pp. 1679-82.
} 
very few US inventors or patent examiners were probably able to read patent specifications written in Italian. For this reason, the use of US patent citations to Italian patents does not seem a suitable approach. On the other hand, Italian law did not prescribe the use of citations for documenting prior art, and therefore, in this period, Italian patent citations did not exist. Hence, the only approach available in the Italian case is to use, as a proxy measure of patent value, the renewal behaviour of the patentee. The use of renewal behaviour to estimate the quality of patents has been adopted as a reasonable working procedure in other recent studies dealing with the same historical period, such as those by Streb, Baten, and Yin, and by Sáiz. ${ }^{47}$

Our dataset allows us to construct two different indicators of patent value. The first is what we label the 'scheduled' length of a patent (measured in years). This is computed by adding to the initial duration all the years for which the patent was prolonged. The intuition is straightforward: patents taken out or prolonged are probably seen, in the eyes of their patentees, as covering more important inventions.

The second proxy of patent value that we construct is what we label the 'real' length. This proxy is measured by the full period for which the fees of the patents were regularly paid by the patentee. To sum up, the first proxy - the 'scheduled' length - may be interpreted as representing an ex ante assessment of the value of the patent, with some possible revisions due to the extensions. Instead, the second proxy - the 'real' length - reflects an ex post assessment of the quality of the patent.

The plausibility of this approach is confirmed by comparing the length of patents registered by Italian residents in Italy with that of patents registered by Italian residents both in Italy and in the US. ${ }^{48}$ The intuition underlying this comparison is that patents also registered in the US system, which was obviously regarded as a very large and significant market by Italian inventors, will typically cover innovations of higher quality. Indeed, it is not likely that an Italian inventor would have made the effort to register a patent in the US system unless he was convinced that he owned a really valuable innovation. Table 4 shows that both for 'scheduled' and for 'real' lengths the mean and median number of years of patents granted both in Italy and in the US are considerably higher than for those granted only in Italy. A non-parametric Mann-Whitney test confirms that these differences between the two distributions are statistically significant. ${ }^{49}$ Overall, the evidence presented in table 4 validates the adoption of Italian renewal data as a suitable proxy for the quality of patents.

Table 5 presents the data on the renewal behaviour of the patentees. The first panel of the table contains the share of patents that expired before their 'scheduled' duration, because the patentees did not pay the renewal fees. Overall the share of expired patents is around two-thirds of the total and it is very similar for independent inventors and firms. In the second panel of the table, we examine the

\footnotetext{
${ }^{47}$ Streb et al., 'Technological and geographical knowledge spillover'; Sáiz, 'Social networks'. On the basis of a detailed empirical study of a large sample of US patents granted in the 1990s, Bessen, 'Value', pp. 940-1, has recently argued that patent citations can be used as a (noisy) indicator of the relative technological significance of a patent, but that renewals are definitely to be preferred as indicators of the economic value of inventions.

${ }^{48}$ We would like to thank Giacomo Domini for sharing with us the data on US patents granted to Italian residents.

${ }^{49}$ We have carried out the Mann-Whitney test because the distributions of the durations in the two samples are skewed and not normal.
} 
Table 4. Duration (years) of patents granted to Italian residents

\begin{tabular}{lccc}
\hline 'Scheduled' length (years) & $\begin{array}{c}\text { All patents } \\
(3,630)\end{array}$ & $\begin{array}{c}\text { Patents granted only } \\
\text { in Italy (3,519) }\end{array}$ & $\begin{array}{c}\text { Patents also granted } \\
\text { in US (111) }\end{array}$ \\
\hline Mean & 4.1 & 4.0 & 8.2 \\
Median & 3.0 & 3.0 & 7.0 \\
Mann-Whitney test (z)=9.749*** & & Patents granted only & Patents also granted \\
\hline & in Ull patents & in (65) \\
'Real' length (years) & $(1,846)$ & 2.7 & 5.7 \\
\hline Mean & 2.5 & 1.0 & 5.0 \\
Median & 1.0 & & \\
Mann-Whitney test $(\mathrm{z})=7.730 * * *$ & & &
\end{tabular}

Note: $* * * \mathrm{p}<0.01$.

Sources: for Italy, MAIC, Bollettino delle privative industriali del Regno d'Italia, 1864-85, 1886-93; idem, Elenco degli attestati di privativa industrial; idem, Bollettino della proprietà intellettuale; Gazzetta Ufficiale del Regno d'Italia, 1881-1915; US patent data retrieved from US Patent Office, Annual Report, 1880-1913; US Patent Office, Official Gazette, 1880-1913. All US sources were accessed on 9 Dec. 2013 via http://catalog.hathitrust.org.

Table 5. Patents expired before 'scheduled' length,

\begin{tabular}{|c|c|c|c|}
\hline & 1881 & 1891 & 1902 \\
\hline \multicolumn{4}{|l|}{ Total } \\
\hline Total no. of patents & 941 & 1,618 & 2,987 \\
\hline Expired & 627 & 1,144 & 1,909 \\
\hline$\%$ & 66.6 & 70.7 & 63.9 \\
\hline \multicolumn{4}{|l|}{ Firm } \\
\hline Total no. of patents & 136 & 298 & 616 \\
\hline Expired & 84 & 213 & 402 \\
\hline$\%$ & 61.8 & 71.5 & 65.3 \\
\hline \multicolumn{4}{|l|}{ Independent } \\
\hline Total no. of patents & 805 & 1,320 & 2,371 \\
\hline Expired & 543 & 931 & 1,507 \\
\hline$\%$ & 67.5 & 70.5 & 63.6 \\
\hline \multicolumn{4}{|c|}{ Average 'real' length (years) } \\
\hline Total & 3.5 & 3.4 & 3.7 \\
\hline Firm & 5.4 & 4.9 & 5.7 \\
\hline Independent & 3.2 & 3.1 & 3.2 \\
\hline Foreign & 4.0 & 3.6 & 4.4 \\
\hline Italy & 2.7 & 2.8 & 2.5 \\
\hline \multicolumn{4}{|c|}{$\begin{array}{l}\% \text { expired in the first year (with } \\
\text { 'scheduled' length }>1 \text { year) }\end{array}$} \\
\hline Total & 30.3 & 32.1 & 29.7 \\
\hline Firm & 19.3 & 22.7 & 15.1 \\
\hline Independent & 32.3 & 34.5 & 34.2 \\
\hline
\end{tabular}

Sources: MAIC, Bollettino delle privative industriali del Regno d'Italia, 1864-85, 1886-93; idem, Elenco degli attestati di privativa industrial; idem, Bollettino della proprietà intellettuale; Gazzetta Ufficiale del Regno d'Italia, 1881-1915.

average 'real' duration in terms of years. As expected, we find that the average duration is higher for firms and foreign inventors. Finally, in the third panel we show the share of patents that expired within the first year of life: this might perhaps be regarded as a sort of 'infant mortality rate' of patents. The mortality rate of about 30 per cent seems quite remarkable, but more importantly there is a significant difference between independent inventors and firms, the former being characterized by a much higher share of patents not surviving the first year. 


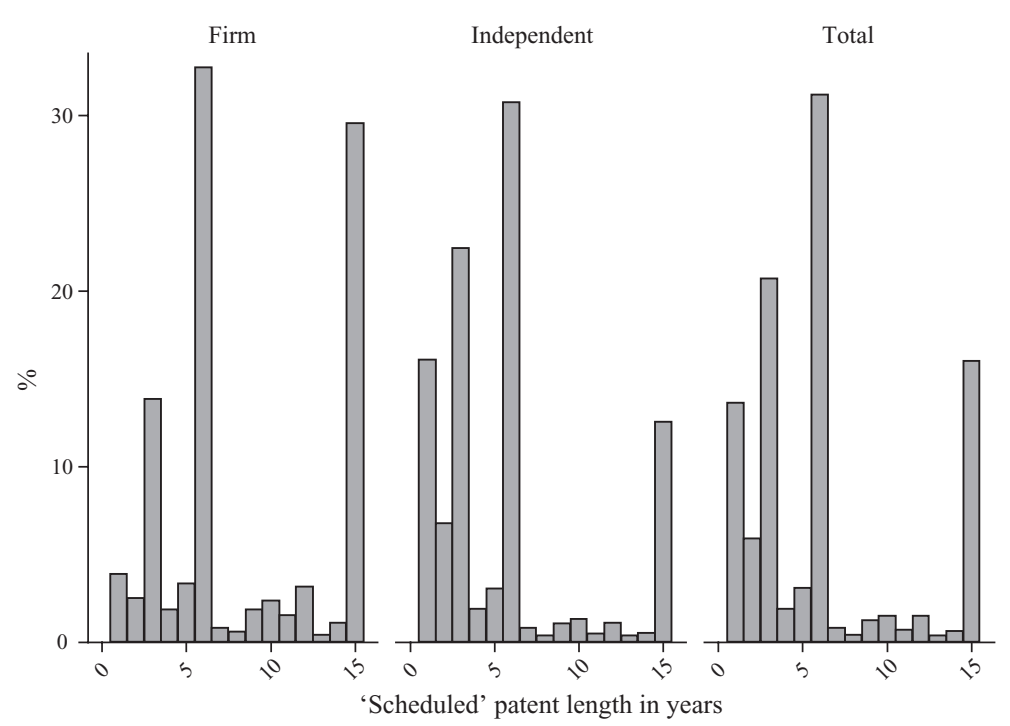

Figure 7. Distribution of 'scheduled' patent length by type of inventor, 1864/5-1911

Sources: MAIC, Bollettino delle privative industriali del Regno d'Italia, 1864-85, 1886-93; idem, Elenco degli attestati di privativa industrial; idem, Bollettino della proprietà intellettuale.

Figure 7 presents the distribution of the 'scheduled' patent length by type of inventor. For both firms and independent inventors, the distribution of 'scheduled' patent length is concentrated on the range between one and six years. There is a peak at six years because Italian law prescribed that a patent taken out for a period of up to five years had to be put into practice within one year from the date when it was granted. ${ }^{50}$ This working requirement was less rigid for patents taken out for longer periods of time, which instead had to be put into practice within two years of the date when they were granted. Interestingly enough, for firms and, to a lesser degree, for independent inventors, the distribution is characterized by a peak at 15 years, the maximum length of the patent.

Figure 8 shows the distribution of 'real' patent length by type of inventor. In this case the total distribution is left skewed with a high concentration of low quality patents, which is a pattern fully in line with similar evidence emerging from contemporary data on patent value. ${ }^{51}$ The distribution of independent inventors and firms seems to be quite similar, even if firms' data present a higher peak for patents of 15 years' duration.

Figure 9 contains histograms of the joint distribution of the two proxy measures of patent value. It is interesting to note that the distribution is not spread evenly on the underlying support and it is concentrated on the range of values from one to six years, with a series of additional peaks for the value of 15 years.

In order to assess fully the quality of the patents of independent inventors in Italy, we estimate an econometric model of the determinants of patent length. As dependent variable we consider the number of years for which each patent was taken out or renewed beyond its initial year. Since the minimum patent life for all

${ }^{50}$ Art. 58, Law of 30 Oct. 1859, and art. 84 of Regolamento.

${ }^{51}$ Silverberg and Verspagen, 'Size distribution'. 


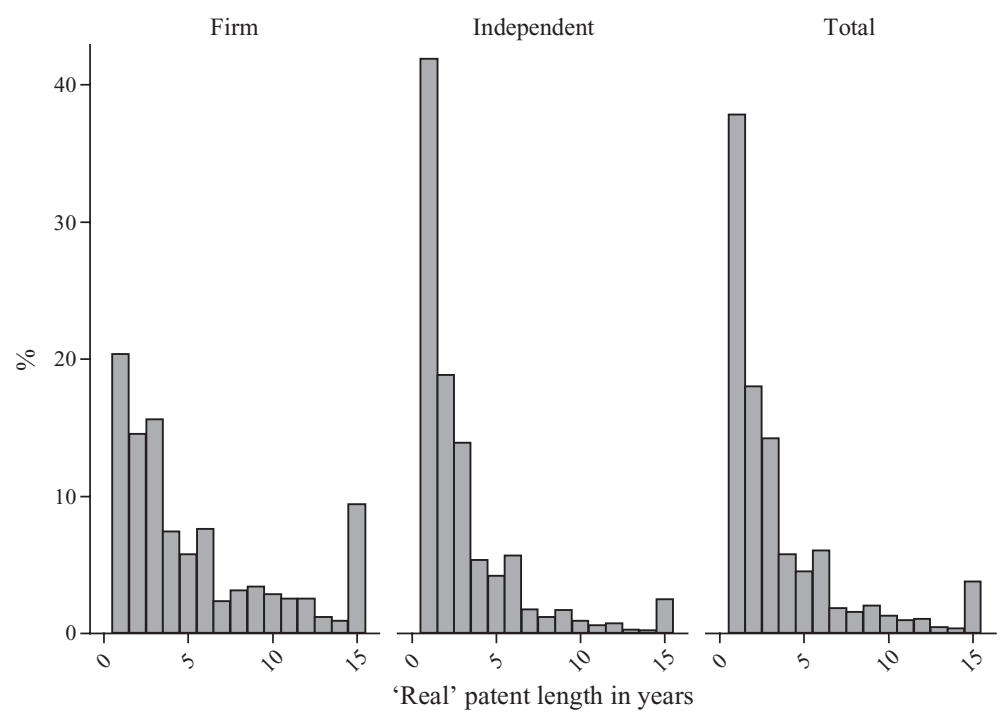

Figure 8. Distribution of 'real' patent length by type of inventor, 1881-1902

Sources: MAIC, Bollettino delle privative industriali del Regno d'Italia, 1864-85, 1886-93; idem, Elenco degli attestati di privativa industrial; idem, Bollettino della proprietà intellettuale; Gazzetta Ufficiale del Regno d'Italia, 1881-1915.

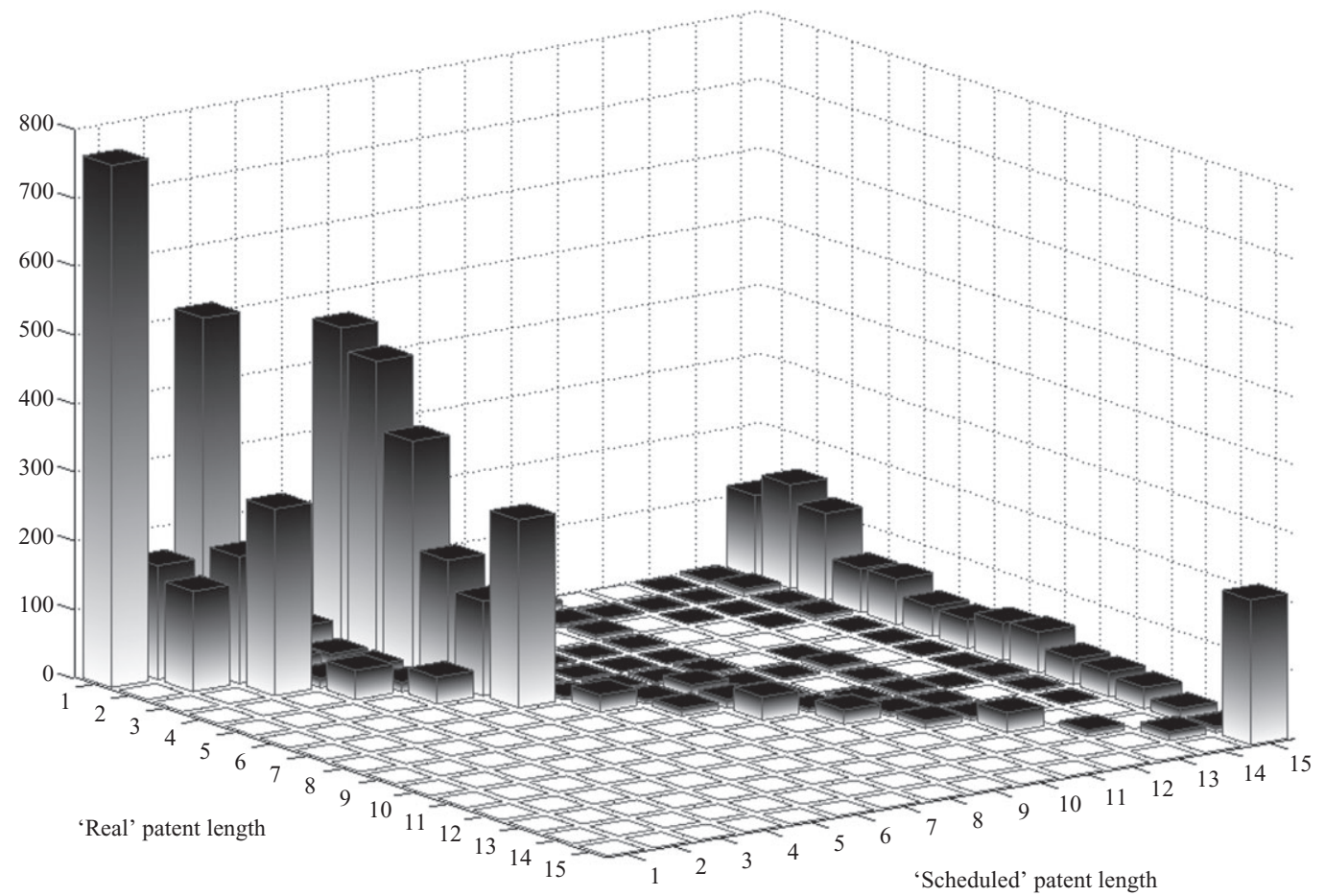

Figure 9. Distribution of 'scheduled' patent length vs. 'real' patent length, 1881-1902 Sources: MAIC, Bollettino delle privative industriali del Regno d'Italia, 1864-85, 1886-93; idem, Elenco degli attestati di privativa industrial; idem, Bollettino della proprietà intellettuale; Gazzetta Ufficiale del Regno d'Italia, 1881-1915. 
patents is one, we can consider as an indicator of patent quality either the complete patent life ranging from one to 15 , or the number of years of renewal beyond the initial year ranging from 0 (when a patent is not renewed beyond its initial year) to 14 (when the patent is at its maximum duration and is renewed for 14 years beyond the initial year). Considering the number of years of renewal beyond the initial year as a measure of patent length allows us to avoid the use of zerotruncated models. Accordingly, we estimate the following count regression model:

E[PATLENGTH|X]

$$
=\exp \left[\alpha I N D E P E N D E N T+\sum_{t} \beta_{t} Y E A R_{t}+\sum_{i} \gamma_{i} I N D U S T R Y_{i}+\sum_{c} \delta_{c} Z_{c}\right]
$$

where PATLENGTH is either the 'scheduled' or 'real' patent length, INDEPENDENT is a dummy variable taking the value of 0 if the patentee is a firm and 1 if the patentee is an independent inventor, $\mathrm{YEAR}_{\mathrm{t}}$ is a set of dummy variables for the different benchmark years of our patent sample, INDUSTRY ${ }_{i}$ is a set of dummy variables for the different industries, and $Z_{c}$ is a set of control variables, including a constant.

In this case, the most suitable econometric approach is the use of a censored Poisson regression model with robust standard errors estimated with the pseudo-maximum likelihood method. ${ }^{52}$ We consider our dependent variable PATLENGTH as right-censored since 14 years is the maximum observable value of PATLENGTH (this means that a patentee was available to renew the patent for a period of at least 14 years). However, it is possible that the assessment of the value of the patent by the patentee would have justified renewing the patent for an even longer period if the law had allowed him this option..$^{53}$

The results for 'scheduled' patent length are reported in table 6. Our variable of interest is INDEPENDENT. We also examine the effects of other covariates such as FOREIGN (a dummy variable indicating a foreign inventor), INDUSTRIAL TRIANGLE (a dummy variable indicating the city of residence of the patentee in one of the three provinces of the Italian industrial triangle), URBAN NOT TRIANGLE (a dummy variable indicating the city of residence of the patentee in one of the major Italian cities, excluding Milan, Turin, and Genoa; in other words, Venice, Bologna, Florence, Rome, Naples, and Palermo), and HIGH TECH (a dummy indicating a patent belonging to the high-tech classes specified in table 3). As mentioned, we control for industry and time effects (the baseline categories being 'textiles, apparel, and leather' and '1902').

We find that INDEPENDENT has a significant and negative effect on patent length across all the specifications, which indicates that patents taken out by

\footnotetext{
${ }^{52}$ Gourieroux, Monfort, and Trognon, 'Pseudo maximum likelihood', have shown that the parameter estimates of the Poisson model are consistent even if the count is not Poisson distributed and the data are characterized by overdispersion.

${ }^{53}$ For a discussion of censored count models, see Hilbe, Negative binomial regression, pp. 387-406. We adopt what Hilbe calls the 'econometric specification' of the Poisson censored model and we consider all observations with a value of 14 as potentially right-censored; see ibid., pp. 395-6. As additional robustness checks, we have also estimated, obtaining fully consistent results, a set of censored negative binomial and of ordered logit regressions, corresponding to the specifications reported in tabs. 6 and 7 .
} 


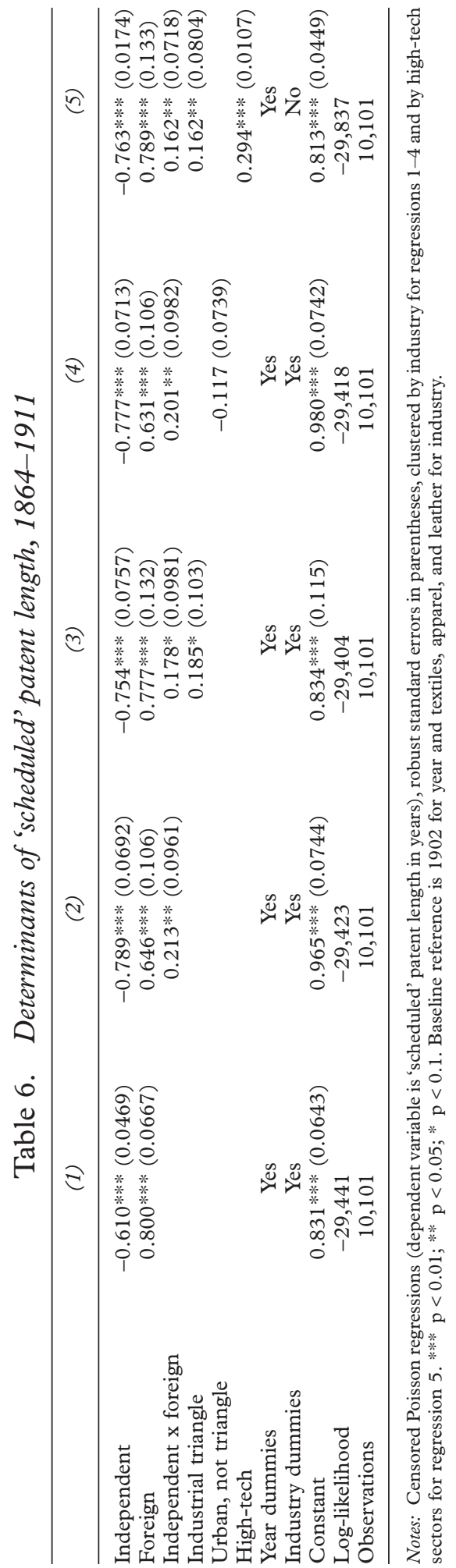


independent inventors were of lower quality than those taken out by firms. ${ }^{54}$ The estimated coefficients imply that independent inventors took out patents with a 'scheduled' duration that was between 45.7 per cent and 54.6 per cent shorter than that of other patentees (the percentage change is computed as [exp(coefficient)-1] x 100). These results are robust across all the specifications. ${ }^{55}$

Moreover, we find a positive and significant effect for the FOREIGN variable, amounting to a patent length 87.9 per cent to 122.6 per cent higher than that of the other patentees (again the percentage change is computed as [exp(coefficient)1] $\mathrm{x}$ 100). It is interesting to observe from columns $2-5$ that independent foreign inventors (INDEPENDENT x FOREIGN) generate patents of higher quality. Therefore our findings suggest the existence of an important difference in the technological contribution of independent inventors, with 'Italian' independent inventors mostly producing patents of reduced quality and 'foreign' independent inventors making valuable innovations. A possible interpretation of this result is that independent foreign inventors decided to take out patents in Italy only for their most valuable inventions.

An important stream of literature has suggested that urban areas constitute environments that can foster innovation and, more generally, inventive activities. ${ }^{56}$ Table 6 shows that these positive urban effects are significant only in the provinces of the 'industrial triangle', which played a pivotal role in the early phase of the Italian industrialization process, and not in other major Italian cities (columns 3-5). Finally, concerning the technological content of the patents, we find that 'high tech' patents were also correlated with a longer patent life.

Table 7 reports the results for regressions similar to those of table 6 , but using as dependent variable the 'real' patent length. These regressions cover only the three benchmark years for which we could calculate the 'real' patent length using renewal data $(1881,1891$, and 1902). Overall, the results are consistent with those obtained in table 6 . In this case the negative impact of independent inventors on the 'real' patent length is significant and higher than in the case of the 'scheduled' patent length. In some specifications the coefficients for FOREIGN and INDEPENDENT $x$ FOREIGN are not significant, and in these cases the localization of the patentee in the 'industrial triangle' does not seem to exert a significant effect on patent length.

Tables 8 and 9 report the results of estimations for each benchmark year. In the case of 'scheduled' patent length (table 8), the coefficients of INDEPENDENT and FOREIGN are not significant in the first benchmark year (1864-5), suggesting that the pattern of innovation we have identified only emerges fully after 1881, as one would probably have expected. As far as the 'real' patent length is concerned

\footnotetext{
${ }^{54}$ Using a similar econometric set-up, Nicholas, 'Independent invention during the rise of the corporate economy', p. 1016, finds a negative coefficient of independent inventors' patents on renewals in Britain, arguing that, although 'the quality of independent invention was high, yet renewal rates were low' because the structure of UK patent fees was expensive and independent inventors may have been impaired in their renewal behaviour by credit constraints. For a discussion of the issue of credit constraints for independent inventors in the UK, see MacLeod, Tann, Andrew, and Stein, 'Evaluating'. As already mentioned, the peculiar structure of Italian renewal fees was not likely to represent a hindrance for the renewal behaviour of independent inventors.

55 The negative size of the coefficient of the INDEPENDENT variable is not likely to be affected by some possible misattributions of corporate patents to independent inventors. Since the average quality of corporate patents is higher than that of independent patents, biases in the direction just mentioned will in general tend to increase the average value of independent inventors' patents.

${ }^{56}$ See, for example, Mokyr, 'Urbanization'.
} 


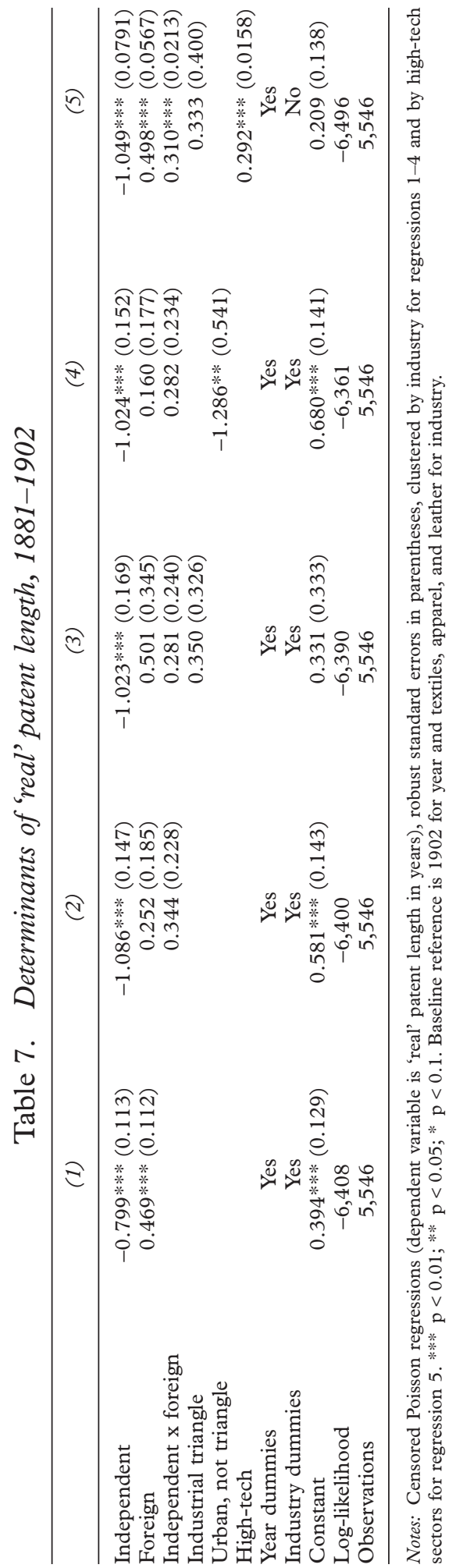




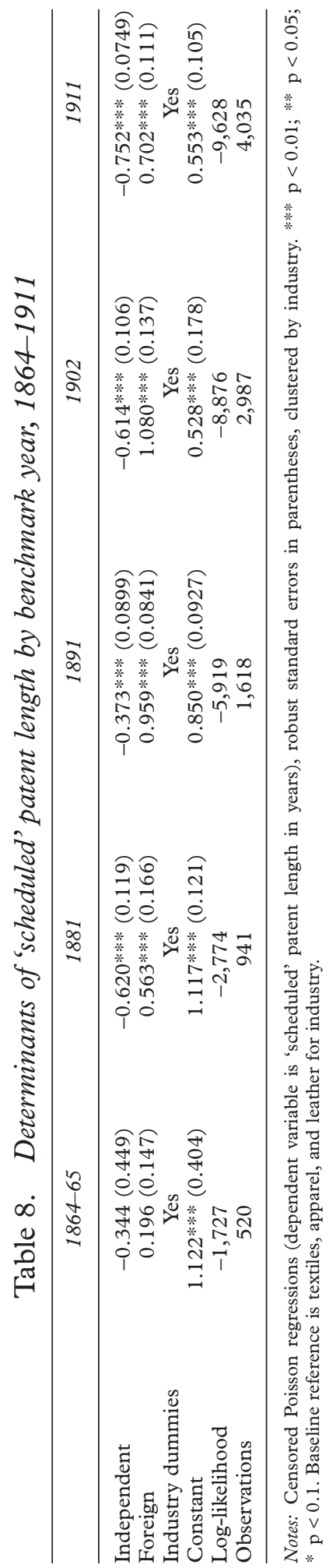


Table 9. Determinants of 'real' patent length by benchmark year, 1881-1902

\begin{tabular}{lccr}
\hline & 1881 & 1891 & 1902 \\
\hline Independent & $-1.284 * * *(0.221)$ & $-0.556 * * *(0.159)$ & $-0.817 * * *(0.161)$ \\
Foreign & $0.650(0.427)$ & $0.248(0.218)$ & $0.523 * * *(0.108)$ \\
Industry dummies & Yes & Yes & Yes \\
Constant & $0.107(0.341)$ & $-0.0434(0.197)$ & $0.214(0.152)$ \\
Log-likelihood & -600.8 & $-1,389$ & $-4,309$ \\
Observations & 941 & 1,618 & 2,987 \\
\hline
\end{tabular}

Notes: Censored Poisson regressions (dependent variable is 'real' patent length in years), robust standard errors in parentheses, clustered by industry. $* * * \mathrm{p}<0.01 ; * * \mathrm{p}<0.05 ; * \mathrm{p}<0.1$. Baseline reference is textiles, apparel, and leather for industry.

(table 9), we find a negative and significant effect: again this is higher than the corresponding effect for 'scheduled' patent length in all three benchmark years $(1881,1891$, and 1902).

\section{V}

Independent inventors remained an important source of innovation during the second industrial revolution, alongside corporate $\mathrm{R} \& \mathrm{D}$ laboratories. This is true in the case of the US, where independent inventors were effectively incentivized by a 'democratic' and reliable patent system. In the case of Britain, Nicholas also shows that independent inventors made an important contribution to technical progress (measured in terms of 'valuable' inventions), notwithstanding the high costs of patent protection. ${ }^{57}$

The Italian case, documented in this article, sheds further light on these issues. During the Liberal Age, Italy was characterized by a relatively cheap and flexible patent system which, at least in principle, seems to have provided very favourable conditions for the activities of independent inventors. Accordingly, the evidence examined in this article shows that independent inventors (both domestic and foreign) made intensive use of the Italian patent system. However, in comparing the Italian with the British case, an important difference becomes apparent. In Britain, a significant share of the innovations patented by independent inventors were of relatively high quality, whereas in Italy independent inventors' patents were clustered in the low quality segment of the innovation quality distribution, measured using renewal rates. ${ }^{58}$ Interestingly enough, these findings are in line with the patterns of innovation in the silk industry described by Federico. The silk industry was one of the few sectors in which, during the period in question, Italy was the universally acknowledged technological leader. According to Federico, in this industry the most valuable innovations were introduced by firms that were specialized suppliers of machines and other pieces of equipment. These firms did not resort to patent protection, but made use of alternative appropriability strategies based on reputation, customer service, and so on. As a result, a large share of patents in this sector was taken by independent inventors. According to Federico's

\footnotetext{
${ }^{57}$ Nicholas, 'Independent invention during the rise of the corporate economy'.

${ }^{58}$ Our results are also consistent with the recent findings reported in Nicholas, 'Technology', tab. 7.1, p. 187. Nicholas shows that during the period 1870-1918 patents registered in the US by Italian inventors were of low quality since they received significantly fewer citations than patents registered in the US by German, French, British, and Japanese inventors.
} 
detailed appraisal, most of these independent inventors' patents were of limited economic and technological significance and very few of them were actually put into practice. ${ }^{59}$

Of course, this evidence raises the question of why Italian independent inventors, despite operating in a seemingly favourable context, failed to act as 'a dynamic source of new technology formation' like their British counterparts. ${ }^{60} \mathrm{We}$ would suggest that two main factors are probably responsible for the relatively low quality of the innovations patented by Italian independent inventors.

The first is the structural weakness of the Italian innovation system (especially in terms of human capital formation) which, in general, did not represent a propitious environment for the generation and development of technological breakthroughs. ${ }^{61}$

The second explanation revolves more closely around the activities of independent inventors and the context in which they worked. A recent stream of literature has highlighted the critical role played by institutional arrangements that are complementary to the functioning of the patent system, such as patent agents and other intermediaries that allow the functioning of 'markets for technologies'. These institutions promote the successful commercial implementation of the innovations generated by independent inventors, either by facilitating transactions in the 'markets for technologies' (licensing or sales of the invention) or by helping to raise the capital for the creation of new companies.

Although the activities of patent agents and other intermediaries in Italy have not yet been studied systematically, it is possible to point to some pieces of qualitative evidence suggesting that the institutional quality of these structures was largely inadequate, at least by international standards. ${ }^{62} \mathrm{~A}$ revealing example is the case of Guglielmo Marconi (1874-1937) and the invention of the radio. Marconi developed his invention in Italy, but he was able to commercialize it successfully only after moving to England. Guagnini has documented the key role played by Carpmael \& Co. (Marconi's patent agents in London) in ensuring both the international appropriability of the invention and the successful gathering of the financial resources necessary for the entrepreneurial exploitation of the invention by means of the creation of a new company. ${ }^{63}$

Another enlightening case is that of Alessandro Cruto (1847-1908). He invented a highly efficient electric light bulb that in a systematic series of experiments in 1883

\footnotetext{
${ }^{59}$ Federico, Filo d'oro, pp. 163-5.

${ }^{60}$ Nicholas, 'Independent invention during the rise of the corporate economy', p. 1022.

${ }^{61}$ On the Italian National innovation system, see Nuvolari and Vasta, 'Ghost in the attic?'. If we compare Italy with Britain in this period, we find that Italy was characterized by significantly lower literacy rates (see Cipolla, Literacy and development, pp. 113-30) and by a lower number of graduates in engineering (see Vasta, Innovazione tecnologica, p. 250).

${ }^{62}$ Some suggestive evidence on the relative backwardness of 'patent agency' in Italy can be gleaned by comparing the number of agents registered in the International Directory of Patent Agents published by William Reeves in London in 1901: 2,193 in the US; 418 in Germany; 286 in the UK; 213 in France; 39 in Spain; and 20 in Italy. We are grateful to Gabriel Galvez-Behar for providing us with these data. The relatively low quality of patents of independent inventors and the limited role played by 'markets for technologies' are also pointed out by Sáiz, 'Social networks', for Spain. Interestingly enough, according to Nicholas and Shimizu, 'Intermediary functions', markets for technologies and related institutions in fact functioned relatively well in the case of Japan, another latecomer country.

${ }^{63}$ Guagnini, 'Patent agents'. For a discussion of the activities of patent agents in Britain in this period in the field of electrical technologies, see Araposthatis and Gooday, Patently contestable.
} 
clearly outperformed Edison's bulb. ${ }^{64}$ After the experiment, Cruto tried to exploit the invention by taking out a patent and creating a new company. However, the commercial success of the firm, because of its inability to exploit the patents on international markets, was short-lived and the firm, after several vicissitudes, was eventually bought by Philips in $1927 .{ }^{65}$

In summary, our findings may be seen as adding an important qualification to those obtained by Nicholas. Independent inventors were a critical source of invention during the period of the second industrial revolution, but it is likely that they could play such a role only when they were supported by an appropriate institutional framework.

Date submitted

Revised version submitted

Accepted
28 September 2013

22 May 2014

8 fuly 2014

\section{DOI: $10.1111 /$ ehr.12087}

${ }^{64}$ Coriasso, 'Alessandro Cruto'.

${ }^{65}$ Other similar examples are those of Antonio Pacinotti (1841-1912) and of the partnership between Eugenio Barsanti (1821-64) and Felice Matteucci (1808-87). Pacinotti invented an extremely promising prototype of the electric dynamo, but he was unable to attract the financial resources necessary for the commercial exploitation of his invention. Finally, Pacinotti's invention was taken up by the French company Gramme, which in the late 1870 s produced a rather successful electric generator. Barsanti and Matteucci developed one of the first internal combustion engines, but, despite their efforts, they did not succeed in making the invention a viable commercial option; see Maiocchi, 'Ruolo delle scienze', pp. 876, 890.

\section{Footnote references}

A'Hearn, B., Auria, C., and Vecchi, G., 'Istruzione', in G. Vecchi, ed., In ricchezza e in povertà: il benessere degli italiani dall'Unità a oggi (Bologna, 2011), pp. 159-206.

Amatori, F., Bugamelli, M., and Colli, A., 'Technology, firm size, and entrepreneurship', in G. Toniolo, ed., The Oxford handbook of the Italian economy since Unification (Oxford, 2013), pp. 455-84.

Araposthatis, S. and Gooday, G., Patently contestable: electrical technologies and inventor identities on trial in Britain (Cambridge, Mass., 2013).

Arora, A., Fosfuri, A., and Gambardella, A., Markets for technology: the economics of innovation and corporate strategy (Cambridge, Mass., 2001).

Barbiellini Amidei, F., Cantwell, J., and Spadavecchia, A., 'Innovation and foreign technology', in G. Toniolo, ed., The Oxford handbook of the Italian economy since Unification (Oxford, 2013), pp. 378-416.

Basberg, B., 'Amateur or professional? A new look at nineteenth century patentees in Norway', Scandinavian Economic History Review (2014), DOI: 10.1080/03585522.2014.948047.

Bernal, J. D., Science and industry in the nineteenth century (1953).

Bessen, J., 'The value of US patents by owner and patent characteristics', Research Policy, 37 (2008), pp. $932-45$.

Bilir, L. K., Moser, P., and Talis, I., 'Do treaties encourage technology transfer? Evidence from the Paris convention', Stanford Univ. working paper (2011).

Bosio, E., Le privative industriali nel diritto Italiano (Turin, 1891).

Broadberry, S. N., Giordano, C., and Zollino, F., 'Productivity', in G. Toniolo, ed., The Oxford handbook of the Italian economy since Unification (Oxford, 2013), pp. 187-226.

Chandler, A. D., Scale and scope: the dynamics of industrial capitalism (Cambridge, 1990).

Cipolla, C. M., Literacy and development in the west (Harmondsworth, 1969).

Coriasso, R., 'Alessandro Cruto', in F. Amatori, ed., Dizionario biografico degli imprenditori italiani, mimeo (n.d.), pp. 650-1.

Federico, G., Il filo d'oro. L' industria mondiale della seta dalla restaurazione alla grande crisi (Venice, 1994).

Felice, E. and Vasta, M., 'Passive modernization? The new Human Development Index and its components in Italy's regions (1871-2007)', European Review of Economic History (2014), DOI: 10.1093/ereh/heu018.

Fenoaltea, S., The reinterpretation of Italian economic history: from the Unification to the Great War (Cambridge, 2011).

Fisk, C., Working knowledge: employee innovation and the rise of corporate intellectual property, 1800-1930 (Cambridge, 2009).

Franchi, L., ed., Codici e leggi del Regno d'Italia accuratamente riscontrati sul testo ufficiale, corredati di richiami e coordinati dal prof. Avv. Luigi Franchi. Leggi e convenzioni sulle privative industriali (Milan, 1904). 
Freeman, C. and Louçã, F., As time goes by: from the industrial revolutions to the information revolution (Oxford, 2001).

Freeman, C. and Soete, L., The economics of industrial innovation (3rd edn. 1997).

Giannetti, R., Tecnologia e sviluppo economico italiano (Bologna, 1998).

Giannetti, R. and Vasta, M., 'Big business (1913-2001)', in A. Colli and M. Vasta, eds., Forms of enterprise in 20th century Italy: boundaries, structures and strategies (Cheltenham, 2010), pp. 25-51.

Gourieroux, C., Monfort, A., and Trognon, A., 'Pseudo maximum likelihood methods: theory', Econometrica, 52 (1984), pp. 681-700.

Griliches, Z., 'Patent statistics as economic indicators: a survey', Fournal of Economic Literature, XXVIII (1990), pp. 1661-707.

Guagnini, A., 'Patent agents, legal advisers and Guglielmo Marconi's breakthrough in wireless telegraphy', History of Technology, 24 (2002), pp. 171-201.

Guagnini, A., 'A bold leap into electric light: the creation of the Società Italiana Edison, 1880-1886', History of Technology, 32 (2014), pp. 155-89.

Hatfield, H. S., The inventor and his world (West Drayton, 2nd edn. 1948).

Hilbe, J. M., Negative binomial regression (Cambridge, 2nd edn. 2011).

Hounshell, D. A., 'The evolution of industrial research in the United States', in R. S. Rosenbloom and W. J. Spencer, eds., Engines of innovation: US industrial research at the end of an era (Boston, Mass., 1996), pp. 13-69.

Jewkes, J., Sawers, D., and Stillerman, R., The sources of invention (rev. edn. 1969).

Khan, B. Z., The democratization of invention: patents and copyrights in American economic development, 1790-1920 (Cambridge, 2005).

Khan, B. Z., 'An economic history of patent institutions', R. Whaples, ed., EH.Net Encyclopedia (2008), http://eh.net/encyclopedia/an-economic-history-of-patent-institutions/ (accessed on 9 Oct. 2014).

Lamoreaux, N. R. and Sokoloff, K. L., 'Intermediaries in the US market for technology, 1870-1920', National Bureau of Economic Research working paper no. 9017 (2002).

Lamoreaux, N. and Sokoloff, K., 'The decline of the independent inventor: a Schumpeterian story?', in F. Scott Kieff and T. A. Paredes, eds., Perspectives on commercializing innovation (Cambridge, 2012), pp. 359-91.

Lamoreaux, N. R., Sokoloff, K. L., and Sutthiphisal, D., 'The reorganization of inventive activity in the United States during the early twentieth century', National Bureau of Economic Research working paper no. 15440 (2009).

Lerner, J., '150 years of patent protection', National Bureau of Economic Research working paper no. 7478 (2000)

MacLeod, C., Tann, J., Andrew, J., and Stein, J., 'Evaluating inventive activity: the cost of nineteenth-century UK patents and the fallibility of renewal data', Economic History Review, LVI (2003), pp. 537-62.

Maddison, A., 'Statistics on world population, GDP and per capita GDP, 1-2008' (2009), http://www.ggdc.net/ maddison/Historical_Statistics/vertical-file_02-2010.xls (accessed on 9 Oct. 2014).

Maiocchi, R., 'Il ruolo delle scienze nello sviluppo industriale italiano', in G. Michele, ed., Scienza e tecnica nella cultura e società Italiana dal Rinascimento a oggi, storia d' Italia, annali, vol. 3 (Turin, 1980), pp. 865-999.

Meyer-Thurow, G., 'The industrialization of invention: a case study from the German chemical industry', Isis, 73 (1982), pp. 363-81.

Mokyr, J., The lever of riches: technological creativity and economic progress (Oxford, 1990).

Mokyr, J., 'Urbanization, technological progress, and economic history', in H. Giersch, ed., Urban agglomeration and economic growth (Berlin, 1995), pp. 3-37.

Morrisson, C. and Murtin, F., 'The century of education', fournal of Human Capital, 3 (2009), pp. 1-42.

Moser, P., 'How do patent laws influence innovation? Evidence from nineteenth-century World's Fairs', American Economic Review, 95 (2005), pp. 1214-36.

Moser, P., Ohmstedt, J., and Rhode, P. W., 'Patent citations and the size of the invented step-evidence from hybrid corn' (2013), http://ssrn.com/abstract=1888191 (accessed on 10 March 2014).

Mowery, D. C. and Rosenberg, N., Paths of innovation: technological change in twentieth century America (Cambridge, 1998).

Nagaoka, S., Motohashi, K., and Goto, A., 'Patent statistics as an innovation indicator', in B. H. Hall and N. Rosenberg, eds., Handbook of the economics of innovation, vol. 1 (Amsterdam, 2010), pp. 1083-127.

Nicholas, T., 'The role of independent invention in US technological development, 1880-1930', fournal of Economic History, 70 (2010), pp. 57-82.

Nicholas, T., 'Cheaper patents', Research Policy, 40 (2011), pp. 325-39.

Nicholas, T., 'Independent invention during the rise of the corporate economy in Britain and Japan', Economic History Review, 64 (2011), pp. 995-1023.

Nicholas, T., 'Technology, innovation and economic growth in Britain since 1870', in R. Floud, J. Humphries, and P. Johnson, eds., The Cambridge economic history of modern Britain, vol. 2 (Cambridge, 2014), pp. 181-204.

Nicholas, T. and Shimizu, H., 'Intermediary functions and the market for innovation in Meiji and Taishō Japan', Business History Review, 87 (2013), pp. 121-49.

Nuvolari, A. and Vasta, M., 'The ghost in the attic? The Italian national innovation system in historical perspective, 1861-2011', Enterprise E Society (forthcoming). 
O'Brien, P. K., 'The micro foundations of macro invention: the case of the Reverend Edmund Cartwright', Textile History, 28 (1997), pp. 201-33.

Sáiz, P., 'Social networks of innovation in the European periphery: exploring independent versus corporate patents in Spain circa 1820-1939', Historical Social Research, 37 (2012), pp. 348-69.

Schankerman, M. and Pakes, A., 'Estimates of the value of patent rights in European countries during the post-1950 period', Economic fournal, 96 (1986), pp. 1052-76.

Schmookler, J., 'Inventors past and present', Review of Economics and Statistics, XXXIX (1957), pp. $321-33$.

Schmookler, J., Invention and economic growth (Cambridge, Mass., 1966).

Scholliers, P. and Zamagni, V., eds., Labour's reward: real wages and economic change in 19th and 20th century Europe (Aldershot, 1995).

Schumpeter, J. A., 'The instability of capitalism', Economic fournal, XXXVIII, 151 (1928), pp. 361-86.

Schumpeter, J. A., Capitalism, socialism and democracy (3rd edn. New York, 1981).

Silverberg, G. and Verspagen, B., 'The size distribution of inventions revisited: an application of extreme value statistics to citation and value measures of patent significance', fournal of Econometrics, 139 (2007), pp. 318-39.

Sokoloff, K. L. and Khan, B. Z., 'The democratization of invention during early industrialization: evidence from the United States, 1790-1846', Fournal of Economic History, L (1990), pp. 363-78.

Streb, J., Baten, J., and Yin, S., 'Technological and geographical knowledge spillover in the German empire, 1877-1918', Economic History Review, LIX (2006), pp. 347-73.

Trajtenberg, M., 'A penny for your quotes: patent citations and the value of innovations', RAND fournal of Economics, 21 (1990), pp. 172-87.

von Tunzelmann, G. N., Technology and industrial progress: the foundations of economic growth (Cheltenham, 1995).

Vasta, M., Innovazione tecnologica e capitale umano in Italia (1880-1914). Le traiettorie tecnologiche della seconda rivoluzione industriale (Bologna, 1999).

Vasta, M., 'Le innovazioni tecnologiche', in V. Castronovo, ed., Storia dell'Ansaldo, vol. 9 (Roma-Bari, 2002), pp. 225-59.

Vasta, M., 'The largest 200 manufacturing firms (1913-2001)', in R. Giannetti and M. Vasta, eds., Evolution of Italian enterprises in the 20th century (Heidelberg, 2006), pp. 87-110.

\section{Official publications}

Gazzetta Ufficiale del Regno d'Italia (various years).

MAIC (Ministero di Agricoltura, Industria e Commercio), Bollettino delle privative industriali del Regno d'Italia (Turin, 1864-85).

MAIC (Ministero di Agricoltura, Industria e Commercio), Bollettino delle privative industriali del Regno d'Italia (Rome, 1886-93).

MAIC (Ministero di Agricoltura, Industria e Commercio), Elenco degli attestati di privativa industriale, di prolungamento, completivi, di importazione e di riduzione (Rome, 1894-1901).

MAIC (Ministero di Agricoltura, Industria e Commercio), Bollettino della proprietà intellettuale (Rome, 1902-16).

US Patent Office, Annual Report of the Commissioner of Patents (1880-1913), http://catalog.hathitrust.org/Record/ 002138126 (accessed on 9 Dec. 2013).

US Patent Office, Official Gazette of the United States Patent Office (1880-1913), http://catalog.hathitrust.org/ Record/000498155 (accessed on 9 Dec. 2013).

USPTO (US Patent and Trademark Office), Technology Assessment and Forecast, Seventh Report (1977).

WIPO (World Intellectual Property Organization), 'Statistics database' (various years), http://www.wipo.int/ ipstats/en/ (accessed on 7 Dec. 2013). 